\title{
Lexikos at Eighteen: An Analysis
}

Gilles-Maurice de Schryver, Department of African Languages and Cultures, Ghent University, Ghent, Belgium; Xhosa Department, University of the Western Cape, Bellville, Republic of South Africa; and TshwaneDJe HLT, Pretoria, Republic of South Africa (gillesmaurice.deschryver@UGent.be)

\begin{abstract}
At eighteen, Lexikos became a major player in the field of linguistics, by being awarded an Impact Factor. This article presents a double analysis of the foundation that led to this success. On the one hand a thorough statistical study is undertaken with regard to all contributors and their contributions to Lexikos. To this end a metadata database was designed, with the aim to answer the question: 'Who publishes what type of material from where and when?' On the other hand a content analysis is carried out which focuses on the actual topics (i.e. 'keywords') in Lexikos. To this end an all-inclusive text corpus containing all the Lexikos material was built, with the aim to answer the question: 'What are the major trends in Lexikos?'
\end{abstract}

Keywords: LEXIKOS, LEXICOGRAPHY, METALEXICOGRAPHY, DICTIONARIES, LEXICOGRAPHERS, METADATA DATABASE, TEXT CORPUS, CONTRIBUTIONS, CONTRIBUTORS, AFFILIATIONS, STATISTICS, TRENDS, ENGLISH, AFRIKAANS, BANTU

Samenvatting: Lexikos op achttienjarige leeftijd: Een analyse. Op achttienjarige leeftijd werd Lexikos een speler van wereldformaat binnen de linguïstiek, door het behalen van een Impact Factor. Dit artikel stelt een dubbele analyse voor van de grondslag die tot dit succes leidde. Aan de ene kant wordt een gedetailleerde statistische studie ondernomen met betrekking tot alle auteurs en hun bijdragen tot Lexikos. Daarvoor werd een metadata-databasis ontworpen, waarmee de volgende vraag wordt beantwoord: 'Wie publiceert welk soort materiaal, van waaruit en wanneer?' Aan de andere kant wordt een inhoudsanalyse uitgevoerd die zich toespitst op de feitelijke onderwerpen (m.n. 'sleutelwoorden') in Lexikos. Daarvoor werd een alles-inclusief tekstcorpus met al het Lexikos materiaal gebouwd, waarmee de volgende vraag wordt beantwoord: 'Wat zijn de voornaamste trends in Lexikos?'

Sleutelwoorden: LEXIKOS, LEXICOGRAFIE, METALEXICOGRAFIE, WOORDENBOEKEN, LEXICOGRAFEN, METADATA-DATABASIS, TEKSTCORPUS, BIJDRAGEN, AUTEURS, AFFILIATIES, STATISTIEKEN, TRENDS, ENGELS, AFRIKAANS, BANTOE

\section{Lexikos: From newborn, to toddler, to adult}

In the foreword to the very first issue of the present journal, the genesis of Lexikos is explained thus: "a formal discussion on lexicography between the editorial staff of the WAT and a group of prominent linguists got off the ground in Stellenbosch in 1989, [and] the staff is attempting to extend this discussion to include the rest of Africa" (Harteveld 1991: xii). From humble but 
enthusiastic beginnings at the Bureau of the Woordeboek van die Afrikaanse Taal (WAT) two decades ago, Lexikos has been on a straight trajectory, indeed extending its discussion throughout, not only in geographical terms but also in terms of the ever-growing variety and quality of the lexicographic topics discussed. Lexikos has now been granted its place amongst the major journals in linguistics, through its inclusion in the Thomson Reuters Web of Science Citation Index since 2005, and the calculation of its impact, by means of an annual Impact Factor, as from last year's issue (De Schryver 2009). It is fitting, therefore, to look back at this point in time - 'Lexikos at Eighteen' - to see how the toddler turned into a teenager, before it will now continue life as an adult.

Lexikos received some stimuli along the way; the most effective of these was the result of the establishment of the African Association for Lexicography (AFRILEX) in 1995, and the subsequent agreement whereby membership of AFRILEX includes a copy of the annual journal Lexikos. As such, Lexikos became the official mouthpiece of AFRILEX.

As a newborn, Lexikos had to find its way, and learn to walk. The first issue, virtually entirely in Afrikaans, was actually a cross between a journal and a Festschrift (cf. also Du Plessis 2008: xi), and was even reviewed (as if it were a book) for the International Journal of Lexicography by the father of modern lexicography: Ladislav Zgusta (1993). From a single file of articles in 1991, the journal morphed into one with multiple subsections, in an attempt to keep abreast of the ever-changing and expanding discipline of lexicography. From Volume 4 to Volume 14, for example, articles were mostly grouped into 'Research Articles' vs. 'Contemplative Articles', in addition to 'Review Articles' and 'Reviews' (of books). In the last volume, Volume 18, by contrast, there are no fewer than twelve categories, from 'Articles' to 'Lexicosoftware' to 'Projects' to 'Lexicosurvey', etc. Other changes include the introduction, in Volume 4, of a 'Review Editor', an 'Advisory Board', an 'Editorial Committee', and a statement of the 'Editorial Objectives' in three languages (Afrikaans, English, and German). Starting with Volume 6, each issue has included 'A Few Words from AFRILEX' (in both Afrikaans and English). 'Instructions to Authors' (again in three languages) first appeared in Volume 8. E-mail addresses for all authors were added for the first time in Volume 11. As of Volume 12, finally, both the 'Editorial Objectives' and the 'Instructions to Authors' have also been presented in a fourth language (French).

The overwhelming majority of the contributions to Lexikos are original studies without any prior traces of publication. ${ }^{1}$ In order to study the first eighteen years of Lexikos, two databases were built. On the one hand a Lexikos Metadata Database was designed, in which all the main bibliometric details of each and every contribution were brought together. On the other hand a Lexikos Corpus was built, containing the full text of each and every contribution that appeared during the first eighteen years. In what follows, both databases are subjected to various queries, with the results of those queries summarized in tables and figures. 


\section{The Lexikos Metadata Database}

\subsection{Number of contributions and number of pages}

There are a total of 6587 pages in Lexikos 1 (1991) through Lexikos 18 (2008), on average 366 pages per year. The actual number of pages per volume may be seen from the line in Figure 1: from about 300 pages in the first few volumes, to about 500 pages in the last few volumes. The number of pages thus continuously rose over the years. In parallel, also the number of contributions rose, as may be seen from the bars in Figure 1: from under 20 contributions in the first two volumes, to about 35 in the last few volumes. There are exactly 543 contributions in all, on average 30 per volume. The Pearson correlation coefficient $r$ between the number of pages and the number of contributions is 0.74 , so the fit is not so good. This, on the whole, points to a widely varying average length of the contributions.

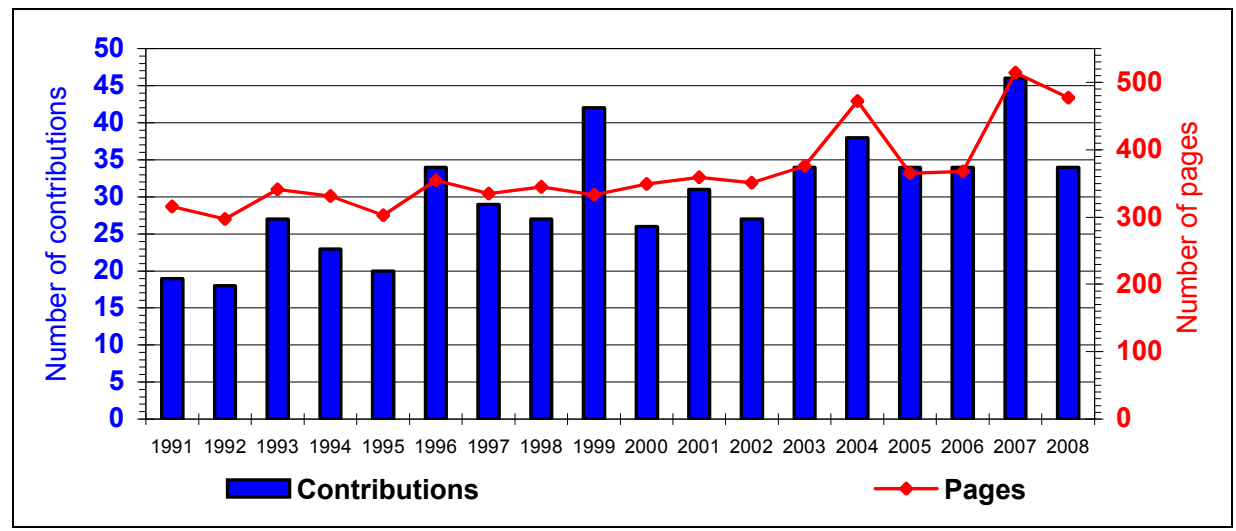

Figure 1: Number of contributions and number of pages in each Lexikos issue

Lexikos is a multilingual journal, and contributions in Afrikaans, English, Dutch, German, and French have all been accepted; distributed as seen in Figure 2. Two conclusions may be drawn from Figure 2: (a) Contributions in languages other than Afrikaans or English are by far in the minority; (b) English has rapidly taken over from Afrikaans as the main language of discourse. The latter may also be confirmed from Figure 3, where the number of Afrikaans and English contributions has been expressed as a percentage of the total per Lexikos issue. While $84 \%$ of the contributions were in Afrikaans in the first issue, this proportion decreases over the years to stabilize to around $20 \%$ (cf. the Afrikaans polynomial trend line). In parallel, while only $16 \%$ of the contributions were in English in the first volume, this proportion increases over the years to stabilize to about 70\% (cf. the English polynomial trend line). (The remainder, $100 \%-20 \%-70 \%=10 \%$, accounts for the 'other languages'.) 


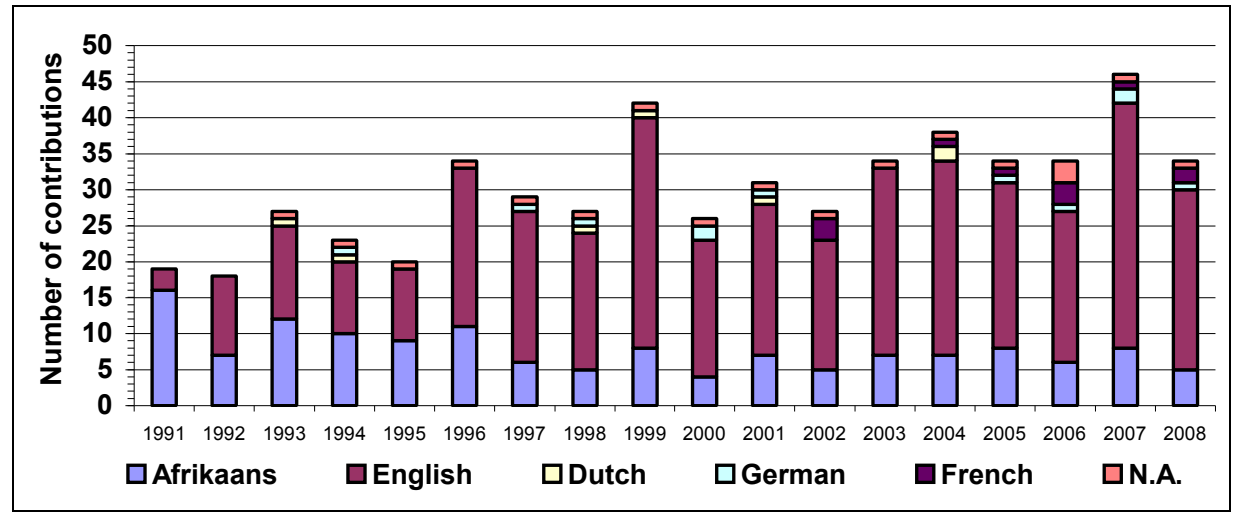

Figure 2: Distribution of the languages in each Lexikos issue

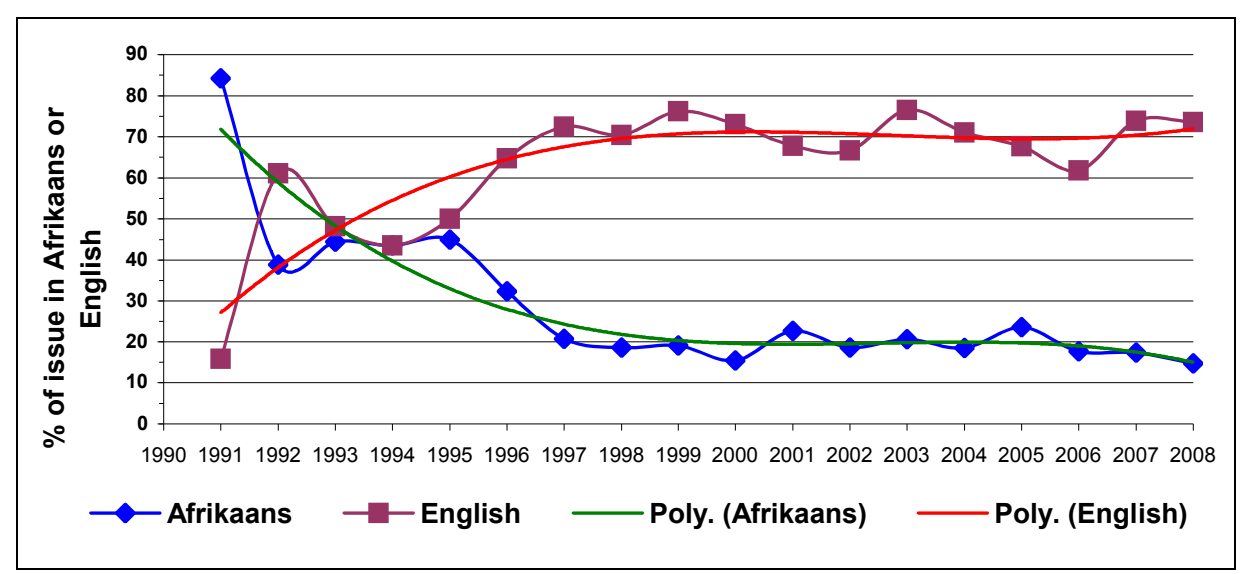

Figure 3: Afrikaans vs. English in each Lexikos issue (expressed as \% of total)

A detailed view of the exact number of contributions and exact number of pages per Lexikos issue is shown in Table 1. From that data one sees that, overall, about $26 \%$ of the contributions in Lexikos are in Afrikaans, $65 \%$ in English, $1 \%$ in Dutch, $2 \%$ in German, and another $2 \%$ in French. A further 3\% cannot be linked to particular languages, as they consist of lists of publications. Once English and Afrikaans had been 'established' as the discourse languages of Lexikos, the next (logical) language that was added was Dutch (from 1993 until 2004), followed by German (since 1994), and then French (since 2002).

Looking at the three main 'peaks' in Figures 1 and 2, finally, one can observe that all three are the results of one-time 'additions': in 2007 a special section was added, called 'Lexicofocus', in which the lexicographic activities at ALRI (in Harare, Zimbabwe) were surveyed; in 2004 a special section on 'Learners' Dictionaries' was added; while in 1999 the full proceedings of a meeting, 'Lexicography in a Multilingual South Africa', was added. Page-wise, 
especially the 2007 and 2004 additions had a great effect (by contrast, the 1999 papers were all short); expressed in number of contributions, all three additions of course had a considerable effect.

Table 1: Detail of the number of contributions and number of pages in each Lexikos issue (with $A=$ Afrikaans, $E=$ English, $N L=$ Dutch, $D E=$ German, $F R=$ French)

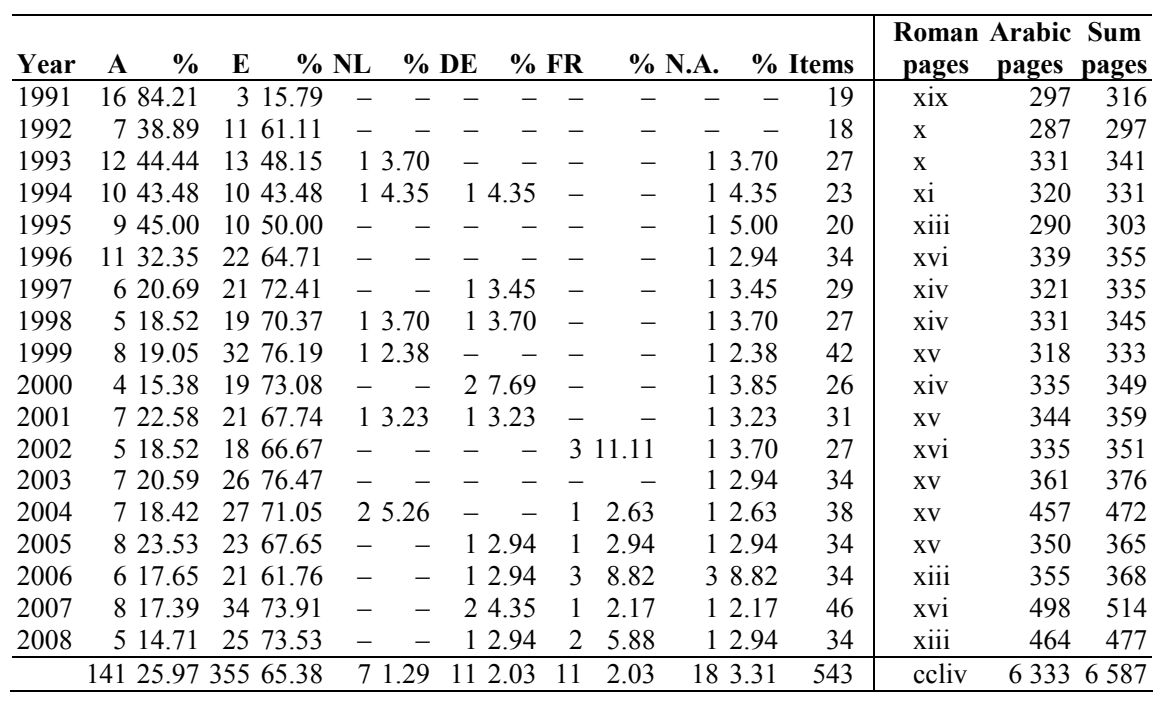

\subsection{Types of contributions}

The second series of queries one can submit to the Lexikos Metadata Database are those concerning the types of contributions. Using the Lexikos-internal categorization, the data shown in Table 2 is obtained.

Table 2: Types of contributions in Lexikos (according to Lexikos-internal categories)

\begin{tabular}{lrr|lrr}
\hline Type & $\mathbf{N}$ & $\mathbf{\%}$ & Type & $\mathbf{N}$ & $\mathbf{\%}$ \\
\hline Review & 111 & 20.44 & Meeting & 14 & 2.58 \\
Article & 106 & 19.52 & Lexicofocus & 10 & 1.84 \\
Contemplative Article & 68 & 12.52 & Lexicosoftware & 6 & 1.10 \\
Editorial Material & 64 & 11.79 & Lexiconews & 2 & 0.37 \\
Research Article & 49 & 9.02 & Lexicotribute & 2 & 0.37 \\
Lexiconote(s) & 26 & 4.79 & Report & 2 & 0.37 \\
Review Article & 23 & 4.24 & Lexicobibliography & 1 & 0.18 \\
Project(s) & 20 & 3.68 & Lexicohonour & 1 & 0.18 \\
Lexicovaria & 19 & 3.50 & Lexicosurvey & 1 & 0.18 \\
Publication Announcements & 18 & 3.31 & & 543 & 100.00 \\
\hline & & & & &
\end{tabular}


Obviously, some of the categories seen in Table 2 should be collapsed, as they are the result of diverging and converging attempts to categorize the various contributions over the years. In regrouping the types, we were inspired by the Web of Science categorization on the one hand, as well as the section on 'type and content of articles' as found in the Lexikos 'Instructions to Authors' (where the main dichotomy is one between articles subjected to strict anonymous refereeing vs. those that are not). Doing so, we obtained seven categories: ARTICLE (i.e. Article, Contemplative Article, Research Article, Lexicofocus, Lexicosoftware, and Lexicosurvey), REVIEW ARTICLE (idem), BOOK REVIEW (i.e. Review), PROCEEDINGS PAPER (i.e. Meeting), OTHER (i.e. Lexiconote(s), Project(s), Lexicovaria, Lexiconews, Lexicotribute, Report, Lexicobibliography, and Lexicohonour), EDITORIAL MATERIAL (idem), and PUBLICATION ANNOUNCEMENTS (idem). The ARTICLE and REVIEW ARTICLE sections are subjected to strict anonymous refereeing; the others must all meet the requirements of academic writing. The resulting distribution is tabulated in Table 3.

Table 3: Types of contributions in Lexikos (inspired by Web of Science categories)

\begin{tabular}{lrr}
\hline Type & N & \% \\
\hline Article & 240 & 44.20 \\
Review Article & 23 & 4.24 \\
Book Review & 111 & 20.44 \\
Proceedings Paper & 14 & 2.58 \\
Other & 73 & 13.44 \\
Editorial Material & 64 & 11.79 \\
Publication Announcements & 18 & 3.31 \\
\hline & 543 & 100.00 \\
\hline
\end{tabular}

As may be seen, as many as $44 \%$ of all contributions to Lexikos are true articles, a further $4 \%$ are review articles, and $20 \%$ are book reviews. ${ }^{2}$

Given that an analogous metadata study was performed for the International Journal of Lexicography (IJL) for the period January 1988 up to December 2008 (cf. De Schryver 2009a), a comparison of the values is instructive. In IJL, one finds $31 \%$ articles, $2 \%$ review articles, and $43 \%$ book reviews. While, in quantitative terms, IJL tends to focus on book reviews, the reverse is true for Lexikos, where most attention goes to articles and review articles.

\subsection{Contributors and their contributions}

A total of 555 names (i.e. name tokens) appear under the 543 Lexikos contributions. These two values are very close, and indeed, most contributions are authored by just one scholar, as may be seen from Table 4 . As many as $83 \%$ of all contributions to Lexikos are written by a single author, a further $12 \%$ by two. There are very few with three, and just two with four - the maximum. By 
contrast, in IJL one finds contributions with up to 12 authors. The single- and co-authored publication values in IJL are, however, very similar to those in Lexikos: $81 \%$ for sole authorship, $13 \%$ for co-authorship.

Table 4: Author position in the Lexikos Metadata Database

\begin{tabular}{lrr}
\hline Author position & $\mathbf{N}$ & $\mathbf{\%}$ \\
\hline 1 & 459 & 82.70 \\
2 & 64 & 11.53 \\
3 & 10 & 1.80 \\
4 & 2 & 0.36 \\
(no author) & 20 & 3.60 \\
\hline & 555 & 100.00 \\
\hline
\end{tabular}

The 555 names that appear under the 543 contributions may be collapsed into 260 different (unique) names. ${ }^{3}$ In other words, a total of 260 different scholars have written material for Lexikos over the past eighteen years. The distribution of the number of contributions for each of those is as shown in Table 5.

Table 5: Number of contributions per author in the Lexikos Metadata Database

\begin{tabular}{crr|crr}
\hline \# contributions & $\mathbf{N}$ & $\mathbf{\%}$ & \# contributions & $\mathbf{N}$ & $\mathbf{\%}$ \\
\hline 1 & 171 & 65.77 & 10 & 1 & 0.38 \\
2 & 42 & 16.15 & 12 & 1 & 0.38 \\
3 & 12 & 4.62 & 14 & 1 & 0.38 \\
4 & 10 & 3.85 & 17 & 1 & 0.38 \\
5 & 6 & 2.31 & 18 & 1 & 0.38 \\
6 & 3 & 1.15 & 20 & 1 & 0.38 \\
7 & 3 & 1.15 & 32 & 1 & 0.38 \\
8 & 2 & 0.77 & 32 & 1 & 0.38 \\
9 & 3 & 1.15 & & 260 & 100.00 \\
\hline
\end{tabular}

Two thirds (66\%) of the contributors to Lexikos only contributed once, $16 \%$ twice, $5 \%$ thrice, etc. In contrast, in IJL as many as three quarters (74\%) contributed only once, $11 \%$ twice, $6 \%$ thrice, etc. Lexikos, then, has far more repeat contributors than IJL. However, the maximum number of contributions for a single contributor stands at around thirty for both journals.

Studying who is behind the high number of contributions, one obtains the data shown in Tables 6 and 7. In Table 6 the focus is on the peer-reviewed contributions: articles and review articles (as regrouped above). The top five here is: Gouws, De Schryver, Prinsloo, Wiegand, and Louw. In Table 7 the focus is on the book reviews. The top five there is: Abecassis, Smit, Louw, Nkabinde, and Swanepoel. The overall top five brings together the Lexikos Editor and the four AFRILEX Presidents so far, rather surprisingly in their tenure order: Gouws (with 32 contributions), Du Plessis (32), Prinsloo (20), Alberts (18), and De Schryver (17). Of course, the high overall ranking for the first four is helped by the editorial material each wrote. ${ }^{4}$ 
Table 6: Top contributors to articles and review articles in Lexikos (with $A=$ article and review article, $B=$ book review, $P=$ proceedings paper, $O=$ other, $E=$ editorial material;,$- \checkmark$ or $\nabla=0,1$ or more than 1 article or review article per year)

\begin{tabular}{|c|c|c|c|c|c|c|c|c|}
\hline \# & Author & Lexikos 1 (1991) through $18(2008)$ & $\mathbf{A}$ & B & $\mathbf{P}$ & $\mathbf{O}$ & $\mathbf{E}$ & $\mathbf{N}$ \\
\hline 1 & Gouws RH & $\checkmark-\nabla \checkmark-\nabla \checkmark \checkmark \checkmark \checkmark \checkmark \checkmark \checkmark \nabla \checkmark \nabla \checkmark \checkmark$ & 20 & 2 & - & - & 10 & 32 \\
\hline 2 & De Schryver G-M & $--------\checkmark \checkmark \nabla \checkmark \checkmark \nabla \nabla \nabla \nabla$ & 16 & 1 & - & - & - & 17 \\
\hline 3 & Prinsloo DJ & $-\checkmark----\checkmark \checkmark-\nabla \checkmark \nabla \checkmark \checkmark-\checkmark--$ & 11 & - & 1 & - & 8 & 20 \\
\hline 4 & Wiegand $\mathrm{HE}$ & $-----\checkmark---\checkmark-\checkmark \checkmark \checkmark \checkmark \checkmark \checkmark \checkmark$ & 9 & - & - & - & - & 9 \\
\hline 5 & Louw PA & $------\checkmark \checkmark \nabla \nabla----\checkmark \checkmark--$ & 8 & 4 & - & - & - & 12 \\
\hline 6 & Otto AN & $--\checkmark \checkmark---\checkmark \checkmark-\checkmark-\checkmark--\checkmark--$ & 7 & 1 & - & - & - & 8 \\
\hline 7 & Swanepoel PH & $\checkmark \checkmark--\checkmark-----\checkmark---\checkmark--\checkmark$ & 6 & 3 & - & - & - & 9 \\
\hline 8 & Carstens A & $---\nabla \nabla-\checkmark-\checkmark---------$ & 6 & 1 & - & - & - & 7 \\
\hline 9 & Alberts M & $-\checkmark-----\checkmark \checkmark-\checkmark \checkmark \checkmark-----$ & 6 & - & - & 4 & 8 & 18 \\
\hline 10 & Botha W & $\checkmark \checkmark \checkmark-\checkmark \checkmark-------\checkmark----$ & 6 & - & - & 1 & - & 8 \\
\hline 11 & Taljard E & $----------\checkmark \checkmark-\nabla--\nabla-$ & 6 & - & - & - & - & 6 \\
\hline 12 & Mavoungou PA & $---------\checkmark \checkmark \checkmark-\checkmark \checkmark--$ & 5 & 1 & - & 1 & - & 7 \\
\hline 13 & Chabata E & $-------\checkmark-\checkmark-\checkmark \checkmark---\checkmark_{-}$ & 5 & - & - & 1 & - & 6 \\
\hline 14 & Tarp S & $---------\checkmark---\nabla--\checkmark \checkmark$ & 5 & - & - & - & - & 5 \\
\hline 15 & Smit M & $-------\checkmark-\checkmark \checkmark \checkmark------$ & 4 & 6 & - & - & - & 10 \\
\hline \multirow[t]{2}{*}{16} & Beyer HL & $-------\checkmark_{-} \checkmark_{-}---\checkmark \checkmark_{-}-$ & 4 & 1 & - & - & - & 5 \\
\hline & Feinauer I & $------\checkmark---------\nabla \checkmark$ & 4 & 1 & - & - & _ & 5 \\
\hline \multirow[t]{2}{*}{18} & Lombard FJ & $\checkmark \checkmark \checkmark \checkmark--------------$ & 4 & - & - & - & - & 4 \\
\hline & Mdee JS & $---\checkmark_{-}-\checkmark_{-} \checkmark_{----} \checkmark_{----}$ & 4 & - & - & - & - & 4 \\
\hline 20 & Potgieter L & $--------------\checkmark \checkmark-\checkmark$ & 3 & 1 & - & - & - & 4 \\
\hline \multirow[t]{4}{*}{21} & Al-Ajmi H & $----------\checkmark----\checkmark-\checkmark$ & 3 & - & - & 1 & - & 4 \\
\hline & Bergenholtz H & $------------\checkmark_{-}-\checkmark_{-}$ & 3 & - & - & 1 & - & 4 \\
\hline & Hadebe S & $-----------\checkmark-\checkmark_{-}-\checkmark_{-}$ & 3 & - & - & 1 & - & 4 \\
\hline & Hartmann RRK & $--\checkmark--\checkmark_{-}------\checkmark_{---}$ & 3 & - & - & 1 & - & 4 \\
\hline \multirow[t]{3}{*}{25} & Gauton R & $----------\checkmark-----\checkmark \checkmark$ & 3 & - & - & - & - & 3 \\
\hline & Joffe D & $--------------\nabla \checkmark--$ & 3 & - & - & - & - & 3 \\
\hline & Kotzé EF & $-\checkmark_{-}---\checkmark_{-} \checkmark_{---------}$ & 3 & - & - & - & - & 3 \\
\hline
\end{tabular}

Table 7: Top contributors to book reviews in Lexikos

\begin{tabular}{lllcccccr}
\hline$\#$ & Author & Lexikos 1 (1991) through 18 (2008) & A & B & P & O & E & N \\
\hline 1 & Abecassis M & $------------\checkmark \checkmark \nabla-\checkmark$ & 2 & $\mathbf{7}$ & - & - & - & 9 \\
2 & Smit M & $------------\checkmark \checkmark-\checkmark \nabla \checkmark$ & 4 & $\mathbf{6}$ & - & - & - & 10 \\
3 & Louw PA & $---------\checkmark \nabla---\checkmark---$ & 8 & $\mathbf{4}$ & - & - & - & 12 \\
4 & Nkabinde AC & $--\square-------------$ & 1 & $\mathbf{4}$ & 1 & - & - & 6 \\
5 & Swanepoel PH & $------\checkmark-----\nabla-----$ & 6 & $\mathbf{3}$ & - & - & - & 9 \\
6 & Heliel MH & $-\checkmark-----\checkmark-\checkmark-------$ & 2 & $\mathbf{3}$ & - & - & - & 5 \\
& Prinsloo AF & $--------\checkmark----\checkmark--\checkmark-$ & 2 & $\mathbf{3}$ & - & - & - & 5 \\
8 & Du Plessis JCMD & $----------\checkmark--\checkmark-\checkmark--$ & 1 & $\mathbf{3}$ & 2 & 2 & 24 & 32 \\
9 & Ridge E & $--\checkmark \checkmark----\checkmark---------$ & - & $\mathbf{3}$ & - & - & - & 3 \\
\hline
\end{tabular}

Also shown in Tables 6 and 7 are the particular volumes of Lexikos in which the articles and review articles on the one hand, and the book reviews on the other, appeared. From these distributions across time, one may conclude that the 
repeat contributors are also 'faithful' contributors to Lexikos, in the sense that once they start contributing, they also tend to continue to contribute over the years. In Table 6 there are only four uneven distributions (Carstens, Smit, Lombard, and Kotzé), and in Table 7 three (Nkabinde, Heliel, and Ridge). Note, further, that the two tables are complementary for three contributors (Smit, Louw, and Swanepoel), whereby a 'gap' in one category actually means that efforts have been put in another category (this is especially the case for Smit, who switched her attention from articles to book reviews over the years). Given that the ticks also tend to cluster near the right-hand side of the time scale, one may further conclude that Lexikos attracts ever more repeat contributors. This finding is clearly a very welcome one, as it bodes well for the future of Lexikos.

\subsection{Continents, countries, cities and affiliations of contributors}

A total of 649 affiliations (i.e. affiliation tokens) accompany the 543 Lexikos contributions. These will now be analysed, starting with a world view down, zooming in on the most productive region(s) at each step.

Although contributions are submitted from every corner of the world, there is a clear bias towards researchers who work from Africa, as seen in Table 8. As many as three quarters (74\%) come from Africa, and 18\% from Europe. Tiny numbers come from the Americas, the Middle-East, Asia and Australasia.

Table 8: Continents of contributors in Lexikos

\begin{tabular}{lrr}
\hline Continent & $\mathbf{N}$ & $\mathbf{\%}$ \\
\hline Africa & 478 & 73.65 \\
Europe & 116 & 17.87 \\
Americas & 12 & 1.85 \\
Middle-East & 10 & 1.54 \\
Asia & 7 & 1.08 \\
Australasia & 5 & 0.77 \\
(no affiliation) & 21 & 3.24 \\
\hline & 649 & 100.00 \\
\hline
\end{tabular}

Within Africa, over $86 \%$ of the contributions come from South Africa, $6 \%$ from Zimbabwe, $2 \%$ from Namibia, etc. See Table 9. The top three for Europe is: Belgium, Germany, and the UK, each with about one-fifth of the contributions from Europe. For the Americas, 10 come from the USA and 2 from Canada; for the Middle-East, 8 come from Kuwait and 2 from Egypt; for Asia, 4 come from Hong Kong and 3 from Japan; and for Australasia, 5 come from Australia.

With about 200 countries in the world, that means that about $15 \%$ is represented in Lexikos. With about 50 countries each in Africa and Europe, about $20 \%$ of the African as well as $20 \%$ of the European countries are represented. The other continents cannot really be said to be represented; rather, they are sampled. 
Table 9: Countries of contributors in Lexikos

\begin{tabular}{|c|c|c|c|c|c|c|c|c|c|}
\hline$\#$ & AFRICA & $\mathrm{N}$ & $\%$ & \# EUROPE & $\mathrm{N}$ & $\%$ & \# AMERICAS & $\mathrm{N}$ & $\%$ \\
\hline 1 & South Africa & 413 & 86.40 & $\begin{array}{ll}1 & \text { Belgium }\end{array}$ & 25 & 21.55 & 1 USA & 10 & 83.33 \\
\hline 2 & Zimbabwe & 31 & 6.49 & 2 Germany & 24 & 20.69 & 2 Canada & 2 & 16.67 \\
\hline 3 & Namibia & 11 & 2.30 & 3 UK & 23 & 19.83 & & 12 & 100.00 \\
\hline 4 & Tanzania & 6 & 1.26 & 4 Denmark & 16 & 13.79 & \# MIDDLE-EAST & $\mathrm{N}$ & $\%$ \\
\hline 5 & Gabon & 5 & 1.05 & Netherlands & 16 & 13.79 & 1 Kuwait & 8 & 80.00 \\
\hline \multirow[t]{2}{*}{6} & Botswana & 3 & 0.63 & 6 Poland & 4 & 3.45 & 2 Egypt & 2 & 20.00 \\
\hline & Kenya & 3 & 0.63 & 7 Sweden & 3 & 2.59 & & 10 & 100.00 \\
\hline \multirow[t]{2}{*}{8} & DR Congo & 2 & 0.42 & 8 Norway & 2 & 1.72 & $\#$ ASIA & $\mathrm{N}$ & $\%$ \\
\hline & Ghana & 2 & 0.42 & 9 Finland & 1 & 0.86 & 1 Hong Kong & 4 & 57.14 \\
\hline \multirow[t]{5}{*}{10} & Nigeria & 1 & 0.21 & France & 1 & 0.86 & 2 Japan & 3 & 42.86 \\
\hline & \multirow[t]{4}{*}{ Zambia } & 1 & 0.21 & \multirow[t]{4}{*}{ Switzerland } & 1 & 0.86 & & 7 & 100.00 \\
\hline & & \multirow{3}{*}{\multicolumn{2}{|c|}{$478 \quad 100.00$}} & & \multirow[t]{3}{*}{116} & \multirow[t]{3}{*}{100.00} & \# AUSTRALASIA & $\mathrm{N}$ & $\%$ \\
\hline & & & & & & & 1 Australia & 5 & 100.00 \\
\hline & & & & & & & & 5 & 100.00 \\
\hline
\end{tabular}

Zooming in on South Africa, where $64 \%$ of all Lexikos contributions come from, one obtains the breakdown in terms of cities shown in Table 10.

Table 10: South African cities of contributors in Lexikos

\begin{tabular}{llrr|llrr}
\hline$\#$ & City & $\mathbf{N}$ & $\mathbf{\%}$ & $\#$ City & $\mathbf{N}$ & $\mathbf{\%}$ \\
\hline 1 & Stellenbosch & 190 & 46.00 & 13 & Potchefstroom & 3 & 0.73 \\
2 & Pretoria & 122 & 29.54 & 14 & Alice & 2 & 0.48 \\
3 & Johannesburg & 18 & 4.36 & & Isipingo & 2 & 0.48 \\
4 & Bellville & 14 & 3.39 & & Mankweng & 2 & 0.48 \\
5 & Polokwane & 11 & 2.66 & 17 & Jeffreys Bay & 1 & 0.24 \\
6 & Bloemfontein & 9 & 2.18 & & Letaba & 1 & 0.24 \\
7 & Port Elizabeth & 8 & 1.94 & & Linden & 1 & 0.24 \\
8 & Grahamstown & 6 & 1.45 & & Mafikeng & 1 & 0.24 \\
& KwaDlangezwa & 6 & 1.45 & & Thornville & 1 & 0.24 \\
10 & Cape Town & 5 & 1.21 & & Upington & 1 & 0.24 \\
11 & Durban & 4 & 0.97 & & Wellington & 1 & 0.24 \\
\cline { 5 - 7 } & Soshanguve & 4 & 0.97 & & & 413 & 100.00 \\
\hline
\end{tabular}

Within South Africa, 46\% emanate from Stellenbosch; the second spot is for Pretoria, with $30 \%$ of all contributions; the third for Johannesburg, with just $4 \%$. Zooming in on Pretoria, as done in Table 11, one sees that several groups at the University of Pretoria as well as at the University of South Africa are very actively contributing to Lexikos, with one third (33\%) from the Department of African Languages at the University of Pretoria alone.

Table 12, lastly, zooms in on Stellenbosch. The two biggest contributing centres here are the Department of Afrikaans and Dutch at the University of Stellenbosch with $39 \%$, and of course, with $45 \%$, the Bureau of the WAT itself - the birthplace of Lexikos, and also where the journal is still being edited and printed. 
Table 11: Lexikos contributors from Pretoria

\begin{tabular}{lrr}
\hline Affiliation & N & $\mathbf{\%}$ \\
\hline University of Pretoria & 54 & 44.26 \\
Department of African Languages & 40 & 32.79 \\
Department of Computer Science & 2 & 1.64 \\
Unit for Language Skills Development & 2 & 1.64 \\
Department of Afrikaans & 1 & 0.82 \\
Northern Sotho NLU - Pretoria Branch & 1 & 0.82 \\
School for Languages & 1 & 0.82 \\
"University of Pretoria" & 7 & 5.74 \\
University of South Africa & 25 & 20.49 \\
Department of Afrikaans (and Theory of Literature) & 9 & 7.38 \\
Department of African Languages & 7 & 5.74 \\
Department of Linguistics & 3 & 2.46 \\
Department of Art History, Visual Arts and Musicology & 2 & 1.64 \\
Department of Criminal and Procedural Law & 1 & 0.82 \\
Department of Criminology & 1 & 0.82 \\
Department of Public Administration & 1 & 0.82 \\
Department of Social Work & 1 & 0.82 \\
TshwaneDJe HLT & 14 & 11.48 \\
Pan South African Language Board (PanSALB) & 11 & 9.02 \\
Department of Arts and Culture & 6 & 4.92 \\
National Terminology Services, Department of National Education & 5 & 4.10 \\
(independent scholar) & 5 & 4.10 \\
Translate.org.za & 1 & 0.82 \\
Unit for African Languages, Human Sciences Research Council & 1 & 0.82 \\
\hline & 122 & 100.00 \\
\hline
\end{tabular}

Table 12: Lexikos contributors from Stellenbosch

\begin{tabular}{lrr}
\hline Affiliation & $\mathbf{N}$ & $\mathbf{\%}$ \\
\hline University of Stellenbosch & 101 & 53.16 \\
Department of Afrikaans and Dutch & 75 & 39.47 \\
Department of Music & 11 & 5.79 \\
SU Centre for Language and Speech Technology (SU-CLaST) & 2 & 1.05 \\
Department of African Languages & 1 & 0.53 \\
Department of Curriculum Studies & 1 & 0.53 \\
Department of Didactics & 1 & 0.53 \\
Department of English & 1 & 0.53 \\
Department of Logistics & 1 & 0.53 \\
Law Faculty & 1 & 0.53 \\
Medicine Faculty & 1 & 0.53 \\
Unit for Afrikaans, Language Centre & 1 & 0.53 \\
Unit for isiXhosa, Language Centre & 1 & 0.53 \\
"University of Stellenbosch" & 4 & 2.11 \\
Bureau of the WAT & 86 & 45.26 \\
(independent scholar) & 3 & 1.58 \\
\hline & 190 & 100.00 \\
\hline
\end{tabular}




\section{The Lexikos Corpus}

In order to transcend the mere bibliometric details discussed in Section 2, a corpus was built consisting of every single contribution in Lexikos so far, except for the 18 lists of 'Publication Announcements'. It thus contains $543-18=525$ files, and after conversion to plain text the size of that corpus is 17MB. The Lexikos Corpus can be loaded into and queried with a corpus tool, just like any other corpus. We used WordSmith Tools (Scott 2009). The total size of the Lexikos Corpus is about 2.5 million running words, with about 100000 distinct words (2 493250 tokens; 103069 types). A subsection of this full corpus was extracted, namely all English contributions, 355 files in all (as there are 170 nonEnglish files, cf. Table 1), good for 1744536 tokens and 65485 types. As a comparison, the English part of the IJL corpus (covering the period January 1988 up to December 2008) contains 592 files, good for 3042282 tokens and 111903 types (cf. De Schryver 2009a).

Why undertake to build such a corpus? The more traditional approach to study journal contents is to assign keywords to each contribution, and then to draw up various tables that show where (i.e. in which issues, and thus which years) certain topics are being discussed. From such manually drawn-up tables one can then attempt to deduce certain trends. Such an approach has been followed for Lexikos before, in an M.A. dissertation (De Schryver 1999: 16-17). Although manual approaches are most definitely valuable, in today's day and age the use of automated approaches with which unlimited amounts of data may be manipulated, and with which that data may be processed and reprocessed ad infinitum, is fast becoming the norm. Querying the Lexikos Corpus thus enables one to 'look' at the full contents of Lexikos all at once.

The main 'tool' that will be used below to do so is WordSmith's KeyWords function, a tool that automatically extracts words that 'stand out' in a first corpus by means of a comparison with the relative frequencies of those same words in a much larger reference corpus. The reference corpus used is the 100million-word BNC World Edition. ${ }^{5}$ Moreover, in order to uncover trends, the English section of the Lexikos Corpus was partitioned in three, as follows:

\section{- $\quad$ Phase 1: 1991-1996 (six years, 69 files) \\ - Phase 2: 1997-2002 (six years, 130 files) \\ - Phase 3: 2003-2008 (six years, 156 files)}

In Addenda 1 to 3, the top 300 keywords in each of these three Lexikos sub-corpora are listed. In analysing those, it is important to recall that the full text of each and every (English language) contribution is included: title, affiliation(s), abstract, keywords, entire article text, endnotes, references, and addenda - as applicable. Given that all these levels are included, one obtains a better picture of what is truly happening in Lexikos, especially compared to a study that would merely take the stated keywords into account, for example. 
The Addenda are a real source of information, and only a few selected aspects can be touched upon within the space of a single journal article. Each of the lists of keywords contains at least seven types of terms:

$\begin{array}{lll}\text { - } & \text { Academic speak } & \text { (cf. next paragraph) } \\ \text { - } & \text { Case study terms } & \text { (cf. next paragraph) } \\ \text { - } & \text { Non-English words } & \text { (cf. next paragraph) } \\ \text { - } & \text { Dictionaries } & \text { (cf. Section 3.1) } \\ \text { - } & \text { Proper names } & \text { (cf. Section 3.2) } \\ \text { - } & \text { Languages } & \text { (cf. Section 3.3) } \\ \text { - } & \text { True keywords } & \text { (cf. Section 3.4) }\end{array}$

'Academic speak' refers to the academic formulae, sentence and thought connectors, as well as abbreviations typically used in academic writing. These include: according, also, as such, based, cf., Ed., Eds., et al., etc., given, in, is, namely, non- $x$, of, or, presented, regard, should, specific, therefore, these, thus, various, and vs. 'Case study terms' are words that have been used in particular case studies and are by consequence very frequent in (some sections of) the corpus. Examples include: kaffir/kaffer, oneself, manifestable, considerate, thoughtful, etc. 'Non-English words' are often also the result of particular case studies or of the text in foreign examples used, such as: bohlale, dipuku, ka, ke, le, morutiši, mosadi, mpša, na, sa, wa, ya, ... in Northern Sotho, or achtung, angst, freude, gefühl, überwinden, ... in German. These are not particularly interesting for the purposes of the current study. The other categories are, and are looked into in the following sections.

\subsection{Dictionaries in Lexikos}

Extracting the dictionary names from the Addenda one obtains Table 13.

Table 13: Dictionaries in the three Lexikos sub-corpora

\begin{tabular}{|c|c|c|c|c|c|}
\hline \multicolumn{2}{|c|}{ Phase 1 (1991-1996) } & \multicolumn{2}{|c|}{ Phase 2 (1997-2002) } & \multicolumn{2}{|c|}{ Phase 3 (2003-2008) } \\
\hline Keyword & Keyness & Keyword & Keyness & Keyword & Keyness \\
\hline WAT & 3039.17 & WAT & 3318.27 & WOORDEBOEK & 2994.28 \\
\hline WOORDEBOEK & 1384.41 & WOORDEBOEK & 2667.21 & WAT & 2895.51 \\
\hline AFRIKAANSE & 1181.81 & AFRIKAANSE & 1515.44 & ISN & 1624.42 \\
\hline OXFORD & 411.96 & COBUILD & 850.31 & AFRIKAANSE & 1530.81 \\
\hline WNT & 360.16 & DICTIONNAIRE & 706.04 & DURAMAZWI & 1396.02 \\
\hline COBUILD & 330.31 & DURAMAZWI & 575.86 & DICTIONNAIRE & 1164.80 \\
\hline $\mathrm{ECD}$ & 300.46 & DGC & 538.35 & OXFORD & 1120.67 \\
\hline DICTIONNAIRE & 270.04 & RECHISHONA & 515.24 & COBUILD & 1083.54 \\
\hline \multirow{4}{*}{ OED } & 267.87 & MACQUARIE & 492.82 & RECHISHONA & 866.49 \\
\hline & & GROOT & 458.70 & LONGMAN & 829.72 \\
\hline & & ISN & 444.37 & ISICHAZAMAZWI & 625.79 \\
\hline & & VERKLARENDE & 434.42 & & \\
\hline
\end{tabular}


The picture is rather stable, both in terms of number of keywords and keyness values. The WAT (Woordeboek van die Afrikaanse Taal) and COBUILD dictionaries appear throughout. During Phase 1, the WNT (Woordenboek der Nederlandsche Taal), the ECD (Explanatory Combinatorial Dictionary), and the OED (Oxford English Dictionary) also receive considerable attention. Moving to Phase 2, Oxford dictionaries disappear out of the top keyword list, while three Zimbabwean dictionaries enter - Duramazwi reChiShona, DGC (Duramazwi Guru reChiShona), and ISN (Isichazamazwi SesiNdebele) -, as well as the Macquarie Dictionary from Australia, the Groot Noord-Sotho woordeboek, the Groot Woordeboek/ Major Dictionary, and the HAT (Verklarende Handwoordeboek van die Afrikaanse Taal). This state is consolidated in Phase 3. Throughout, a variety of French dictionaries is also referred to.

\subsection{Lexicographers in Lexikos}

There are two types of names in the corpus: personal and place names. Extracting all personal names from the Addenda one obtains Table 14.

Table 14: Lexicographers in the three Lexikos sub-corpora

\begin{tabular}{|c|c|c|c|c|c|}
\hline \multicolumn{2}{|c|}{ Phase 1 (1991-1996) } & \multicolumn{2}{|c|}{ Phase 2 (1997-2002) } & \multicolumn{2}{|c|}{ Phase 3 (2003-2008) } \\
\hline Keyword & Keyness & Keyword & Keyness & Keyword & Keyness \\
\hline HARTMANN & 1301.68 & WIEGAND & 7095.03 & GOUWS & 3321.64 \\
\hline WIEGAND & 984.95 & GOUWS & 2121.63 & SCHRYVER & 3163.63 \\
\hline HAUSMANN & 766.13 & PRINSLOO & 1665.49 & WIEGAND & 3051.72 \\
\hline BLOUNT & 686.81 & HAUSMANN & 1543.78 & BERGENHOLTZ & 2464.73 \\
\hline BRANFORD & 559.64 & WIEGAND'S & 1353.79 & TARP & 2134.20 \\
\hline ZGUSTA & 495.23 & SCHRYVER & 1261.29 & PRINSLOO & 2133.77 \\
\hline NADEN & 478.79 & ALBERTS & 682.21 & HARTMANN & 1518.58 \\
\hline GOUWS & 472.71 & GILLES & 653.54 & HESSELING & 1232.34 \\
\hline OSSELTON & 270.12 & BERGENHOLTZ & 636.47 & PHILIPPSON & 1213.09 \\
\hline TONO & 269.36 & ZGUSTA & 626.37 & GILLES & 1105.95 \\
\hline ILSON & 258.87 & KRIEL & 599.05 & HAUSMANN & 1047.65 \\
\hline MEL'CUK & 247.61 & HARTMANN & 592.92 & CHIMHUNDU & 991.65 \\
\hline & & TARP & 585.90 & SCHOLTZ & 983.35 \\
\hline & & CLUVER & 575.86 & ZGUSTA & 847.23 \\
\hline & & LOUW & 557.01 & MAVOUNGOU & 808.72 \\
\hline & & LOUWRENS & 545.55 & HADEBE & 711.44 \\
\hline & & WYK & 541.63 & BOSMAN & 683.80 \\
\hline & & SMIT & 525.56 & SVEN & 683.58 \\
\hline & & SAGER & 474.41 & NIENABER & 655.69 \\
\hline & & KONERDING & 444.52 & HÜLLEN & 654.68 \\
\hline & & & & MAROLE & 606.54 \\
\hline & & & & TOIT & 599.28 \\
\hline & & & & RAPONDA & 548.77 \\
\hline & & & & MAURICE & 547.90 \\
\hline & & & & HENNING & 545.84 \\
\hline & & & & JOFFE & 544.51 \\
\hline
\end{tabular}


One firstly observes that the number of lexicographers competing for keyword status grows with each new phase (those scholars thus displace true lexicographic keywords, cf. Section 3.4). While the 'big shots' Hartmann, Wiegand, Hausmann and Zgusta are represented throughout, the overpowering presence of Wiegand in Phase 2 (note his keyness value there!) is astonishing. If anything, this points to Lexikos's openness towards metalexicography. With each volume of Lexikos, Gouws is gathering more and more attention; see how he rises through the phases. Important here is that his keyness values also increase at each step. The fact that Zgusta seems to go down from one phase to the next is thus misleading: his keyness values too, are increasing at each step; cf. the highlights in Table 14.

\subsection{Languages in Lexikos}

Extracting the languages from the Addenda one obtains Table 15.

Table 15: Languages in the three Lexikos sub-corpora

\begin{tabular}{lr|lr|lr}
\hline \multicolumn{2}{c|}{ Phase 1 (1991-1996) } & \multicolumn{2}{c|}{ Phase 2 (1997-2002) } & \multicolumn{2}{c}{ Phase 3 (2003-2008) } \\
\hline Keyword & Keyness & Keyword & Keyness & Keyword & Keyness \\
\hline AFRIKAANS & 11942.42 & AFRICAN & 7485.60 & ENGLISH & 9489.79 \\
ENGLISH & 8755.20 & ENGLISH & 6987.90 & SHONA & 8319.34 \\
AFRICAN & 4861.51 & AFRIKAANS & 5313.14 & NDEBELE & 7895.39 \\
DUTCH & 3783.88 & SOTHO & 3946.56 & AFRIKAANS & 6101.93 \\
SWAHILI & 2202.69 & HAUSA & 3424.94 & AFRICAN & 5608.01 \\
YIDDISH & 1664.82 & SEPEDI & 3212.81 & SOTHO & 4607.16 \\
ZULU & 1365.02 & SHONA & 3058.44 & SWAHILI & 3051.10 \\
JEWISH & 1310.92 & ZULU & 1648.46 & SESOTHO & 3029.74 \\
ARABIC & 1151.52 & NDEBELE & 1485.13 & LEBOA & 2512.87 \\
XHOSA & 1144.14 & XHOSA & 1335.53 & ZULU & 2401.48 \\
NETHERLAND & 1057.53 & SWAHILI & 1289.27 & SETSWANA & 1778.25 \\
SOTHO & 945.81 & SESOTHO & 1122.08 & FRANÇAIS & 1771.51 \\
BENG & 826.54 & FRANÇAIS & 990.08 & VENDA & 1409.96 \\
MALAYU & 810.37 & ARABIC & 879.79 & BANTU & 1169.46 \\
AMERICAN & 692.96 & BANTU & 834.20 & ISIXHOSA & 982.02 \\
KISWAHILI & 480.59 & CILUBÀ & 788.02 & SHANGANI & 953.14 \\
HOTTENTOT & 478.79 & ISIXHOSA & 616.27 & TSHIVENDA & 943.51 \\
MUSLIM & 478.49 & ISIZULU & 606.17 & SEPEDI & 905.00 \\
ISIXHOSA & 472.71 & DUTCH & 519.55 & YILUMBU & 895.37 \\
BANTU & 441.47 & SETSWANA & 518.29 & KHWE & 779.84 \\
ASHKENAZIC & 384.80 & NOORD & 515.43 & DEUTSCH & 690.33 \\
SHONA & 358.27 & NORTHERN & 456.66 & HAUSA & 685.63 \\
KISI & 337.65 & VENDA & 454.28 & KISWAHILI & 669.92 \\
NORTHEASTERN & 331.40 & SWEDISH & 442.12 & YIPUNU & 616.17 \\
MALAYO & 292.63 & & & NGUNI & 605.85 \\
AUSTRALIAN & 261.75 & & & DANISH & 591.96 \\
OTJIHERERO & 247.61 & & & & 577.66 \\
NGUNI & 239.39 & & & & \\
\hline
\end{tabular}


Note that, with 'Languages in Lexikos', we are not referring to the languages in which the contributions are written (this aspect was dealt with above, cf. Figure 2 ), but to the languages that are the objects of the investigations. Those languages are overwhelmingly English and Afrikaans, and a good number of Bantu languages. Most key Bantu languages are the (official) South African ones, in addition to: Swahili (Kiswahili), Shona (with dialect Zezuru), Cilubà, Otjiherero, Shangani, Yilumbu, and Yipunu. African non-Bantu languages include: Beng, 'Hottentot', Kisi, Hausa, and Khwe. Also key are: Dutch, New Netherland Dutch, and Cape Muslim Afrikaans; (Northeastern) Yiddish, Jewish, and Arabic; American English, Ashkenazic English, and Australian English; French, Swedish, German, and Danish; as well as Malayu/o.

Although this is an interesting distribution, one cannot escape the fact that these language lists are biased towards the official South African languages, so this warrants a more in-depth study. To do so, eighteen different sub-corpora were built, one for each Lexikos volume, from which all non-English contributions were again subtracted. Comparing each of these eighteen sub-corpora with the BNC, keyness values can now be calculated 'per year', and set out graphically. ${ }^{6}$ In Figure 4 this is done for the keywords Afrikaans, English and Bantu.

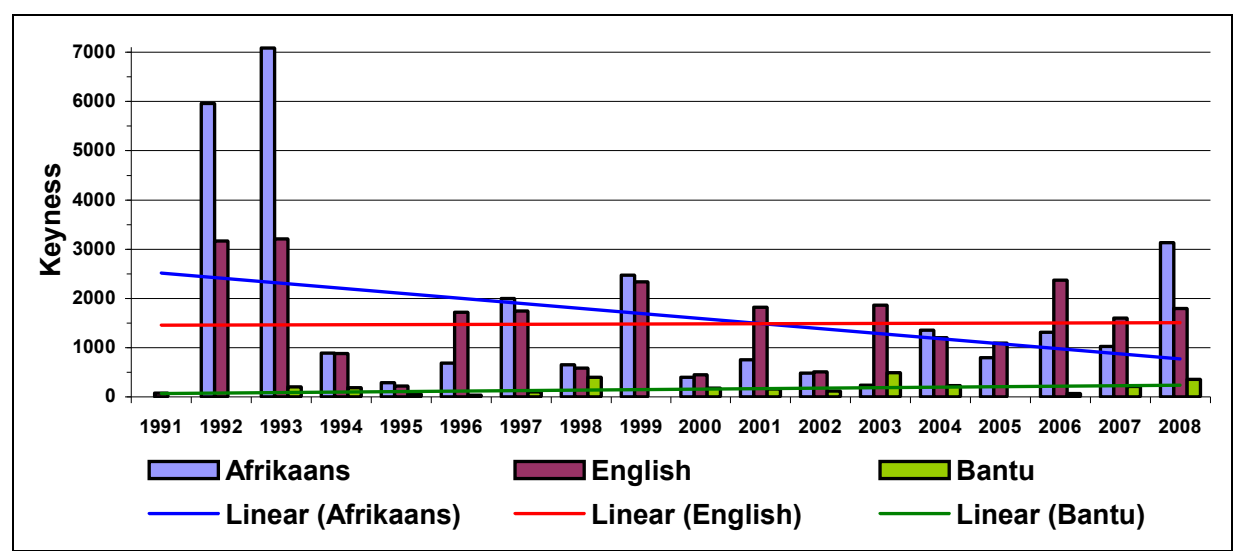

Figure 4: Keyness values for Afrikaans, English and Bantu in each Lexikos issue

On the whole, the keyness value of Afrikaans is decreasing over the years, that of English is mostly stable, while that of Bantu rises only slightly. The term 'Bantu' being stigmatized in South Africa, even with reference to the language family, it is not entirely surprising that the term is not really picking up speed.

In order to unravel the real trends, then, one needs to go down to the language level. In Figure 5 this is done for the so-called Sotho group of southern Bantu languages. Note, however, that 'Sotho' can refer to the group itself, but also to two of its members (Northern Sotho and Southern Sotho), while 'Sesotho' can refer to Southern Sotho or even Northern Sotho when that language is referred to in Northern Sotho itself, viz. as 'Sesotho sa Leboa'. Sepedi, although 
actually but one of the dialects of Northern Sotho, normally unambiguously refers to Northern Sotho. The third member of the Sotho family is unproblematic: it is either referred to as Tswana (in English) or Setswana (in Tswana). Regardless of these ambiguities, it is clear from Figure 5 that the Sotho languages started to be increasingly discussed from 1997 onwards, and peaked for about seven years, from 2001 until 2007. The main language within the family being discussed is Northern Sotho (with often, for Lexikos 12 for example, all research articles devoted to it).

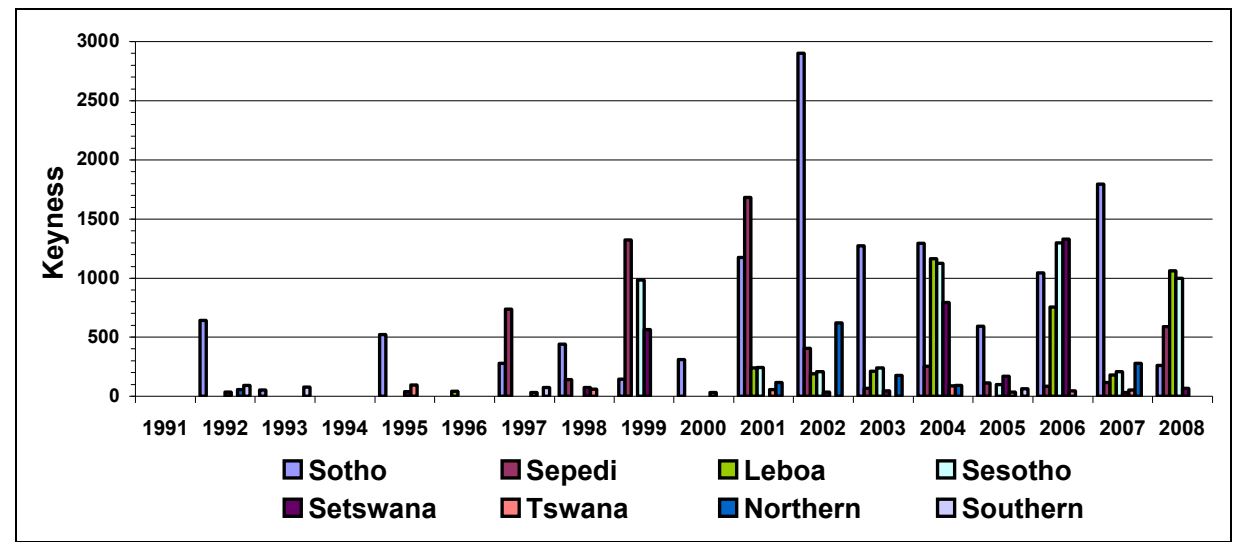

Figure 5: Keyness values for 'Sotho languages' in each Lexikos issue

Moving to the Nguni family of southern Bantu languages, one notes that one member is ambiguous: 'Ndebele', as it can refer to the Ndebele spoken in South Africa (isiNdebele in the language) or Zimbabwean Ndebele. The extreme values for Ndebele in Figure 6 are actually mostly for Zimbabwean Ndebele.

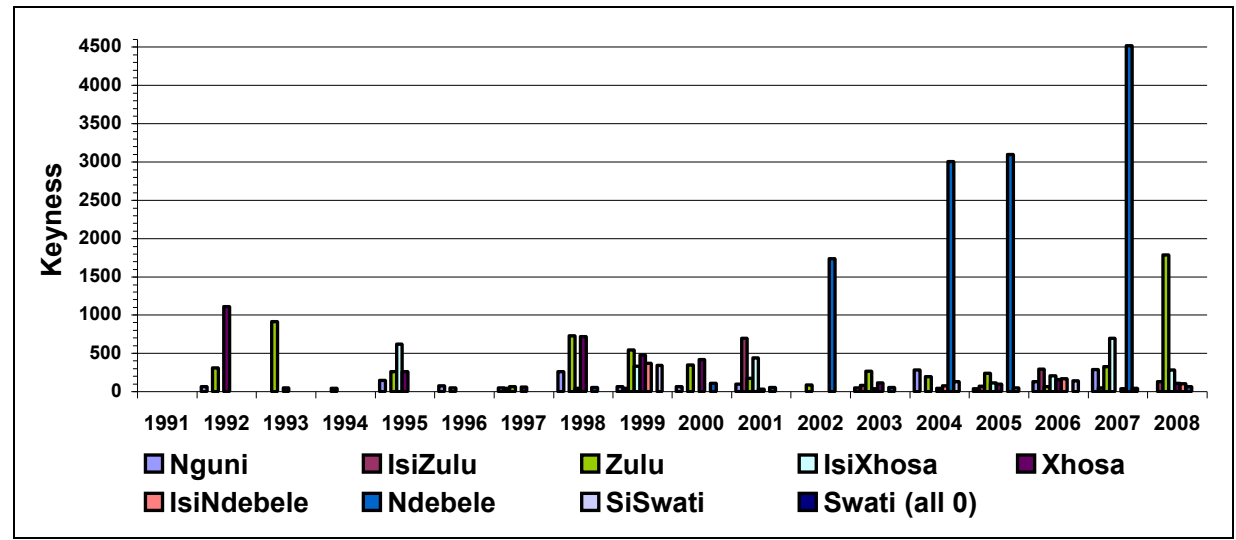

Figure 6: Keyness values for 'Nguni languages' in each Lexikos issue 
Compared to the Sotho family, then, the Nguni family of languages is not frequently discussed in Lexikos, except for the period 1998-2001, and starting with 2008 for Zulu. 1992 was also a good year for Xhosa.

To complete the picture for the official South African languages, Figure 7 displays the keyness values for Venda (Tshivenda) and Tsonga (Xitsonga). Both these languages are not often discussed, with their keyness values on the whole (much) lower than for the other official South African languages.

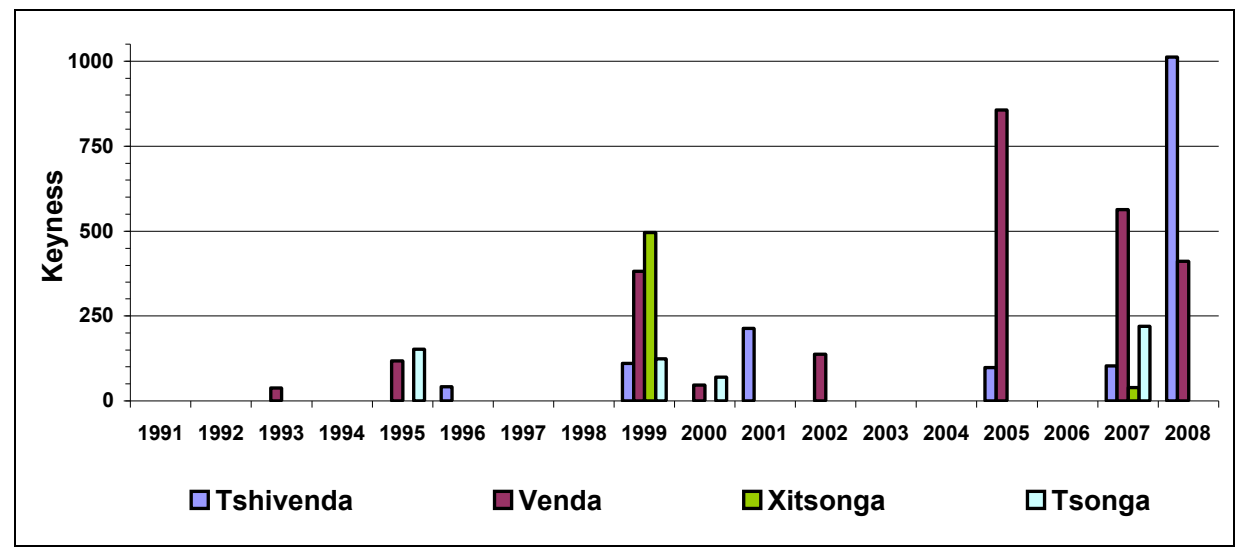

Figure 7: Keyness values for Venda and Tsonga in each Lexikos issue

\subsection{Key topics in Lexikos}

Most of the remaining keywords in Addenda 1 to 3 are true keywords. Analysing those brings out the real features of a journal like Lexikos. A few groups of related keywords and their patterns will be looked into below and, where relevant, comparisons will be made with the corresponding patterns found in IJL (cf. De Schryver 2009a).

\subsubsection{Parts of Speech (POSs)}

In Table 16 the parts of speech (POSs) as well as a few related terms relevant for the study of Bantu languages - all excerpted from the addenda - have been tabulated. The differences between the three phases are striking. In Phase 1, only two POSs stand out: verbs and nouns (together with the related plural), and for the Bantu languages also stem, reflexive, ideophone, and prefix. Going to Phase 2, copulative (and also singular) is added to the basic core; and going to Phase 3, adverb, demonstrative, adjective, and pronoun are further added, as well as suffix and cl. (class) for the Bantu languages, and even POS (part of speech) itself. The list of word classes studied from a lexicographic point of view most definitely grows with the years in Lexikos, and in that it is the opposite from the 
IJL pattern. Actually, following the IJL study we 'predicted' that such lists of POSs would only grow whenever 'new' languages would become the object of lexicographic investigation. This is the case in Lexikos, where many of the languages are being described for the very first time.

Table 16: Parts of speech (POSs) in the three Lexikos sub-corpora

\begin{tabular}{lc|lc|lr}
\hline \multicolumn{2}{c|}{ Phase 1 (1991-1996) } & \multicolumn{2}{c|}{ Phase 2 (1997-2002) } & \multicolumn{2}{c}{ Phase 3 (2003-2008) } \\
\hline \multicolumn{2}{l|}{ Keyword } & Keyness & Keyword & Keyness & \multicolumn{2}{c}{ Keyword } & Keyness \\
\hline VERB & 2440.16 & VERB & 2335.04 & VERB & 1791.75 \\
VERBS & 1782.64 & NOUN & 2218.57 & NOUN & 1481.39 \\
NOUN & 1305.44 & NOUNS & 1327.65 & ADVERBS & 1314.56 \\
NOUNS & 1209.48 & COPULATIVE & 1091.27 & NOUNS & 1219.52 \\
STEM & 596.12 & VERBS & 1054.38 & VERBS & 1191.18 \\
REFLEXIVES & 562.76 & COPULATIVES & 798.12 & DEM & 1068.77 \\
IDEOPHONES & 450.20 & PLURAL & 734.68 & ADJ & 981.19 \\
PLURAL & 436.76 & SINGULAR & 609.03 & SUFFIX & 980.06 \\
PREFIX & 387.42 & PREFIX & 549.19 & ADJECTIVES & 912.92 \\
PREFIXES & 287.91 & STEM & 487.98 & ADJECTIVE & 870.45 \\
& & PLURALS & 440.21 & CL & 830.74 \\
& & & & PRON & 820.91 \\
& & & & POS & 748.93 \\
& & & & COPEFIX & 665.35 \\
& & & & VERBAL & 655.69 \\
\hline
\end{tabular}

\subsubsection{N-lingual lexicography}

Monolingual, bilingual, trilingual and multilingual lexicography are all being discussed in Lexikos, but not in equal proportions, and those proportions change with time, as summarized in Figure 8.

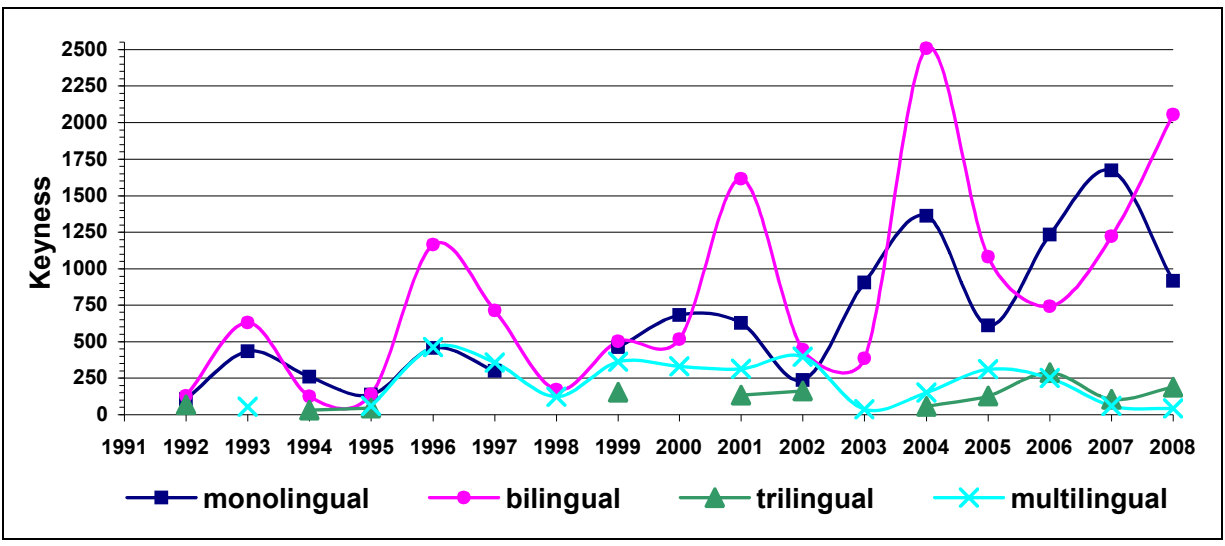

Figure 8: Keyness values for n-lingual in each Lexikos issue 
Overall, bilingual lexicography is more popular than monolingual and multilingual lexicography in lexicographic discussions. While trilingual lexicography only appears sporadically, multilingual topics are actually slightly decreasing. Both bilingual and monolingual lexicography are on the rise, with the acceleration of the former greater than that of the latter.

The core task in monolingual lexicography is defining, so one could investigate whether the occurrence of key terms like defining, definition(s) or explanatory have changed during the past eighteen years. Apart from one peak for definitions in 2007, all these key terms remained stable, as seen in Figure 9.

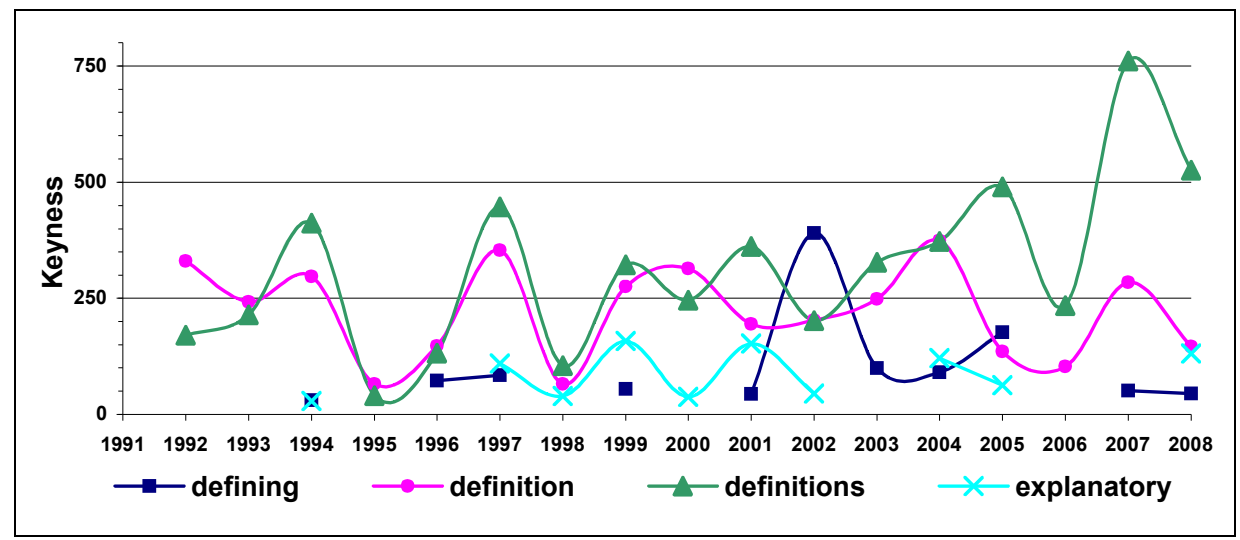

Figure 9: Keyness values for defining etc. in each Lexikos issue

Likewise, the core task in bilingual lexicography is to provide translation equivalents, so Figure 10 shows whether or not changes have occurred in this regard, looking at the key terms equivalence, equivalent(s), translating, and translation(s). Here one notices an increased activity for the period 2002-2004.

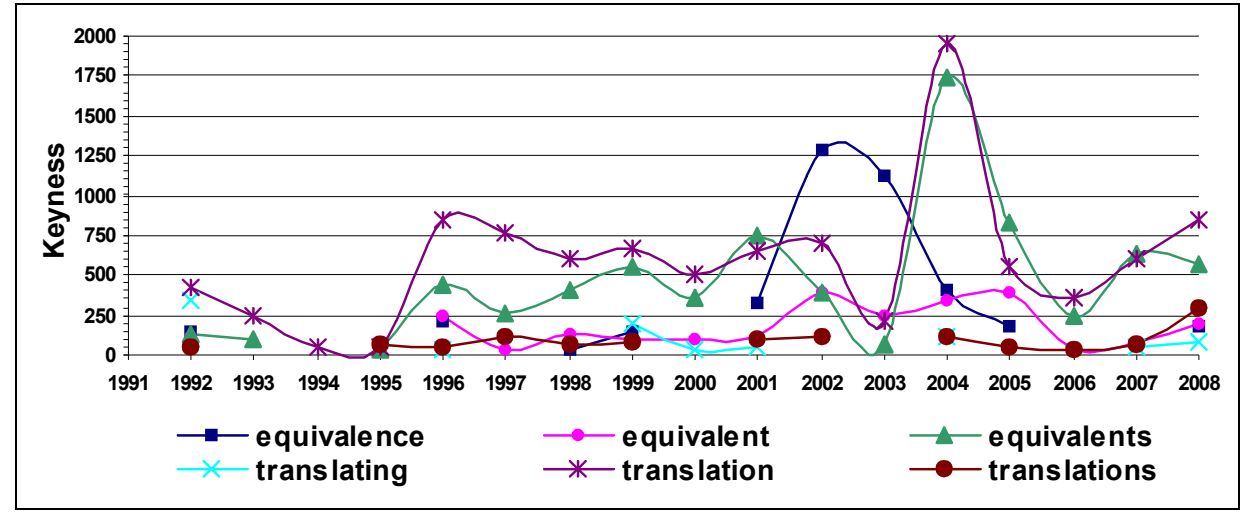

Figure 10: Keyness values for translating etc. in each Lexikos issue 


\subsubsection{Terminology and terminography}

With regard to the sub-disciplines of terminology and terminography, Figure 11 clearly indicates that there has been a flurry of activity in the period 19972004, especially in the years 2000 and 2002.

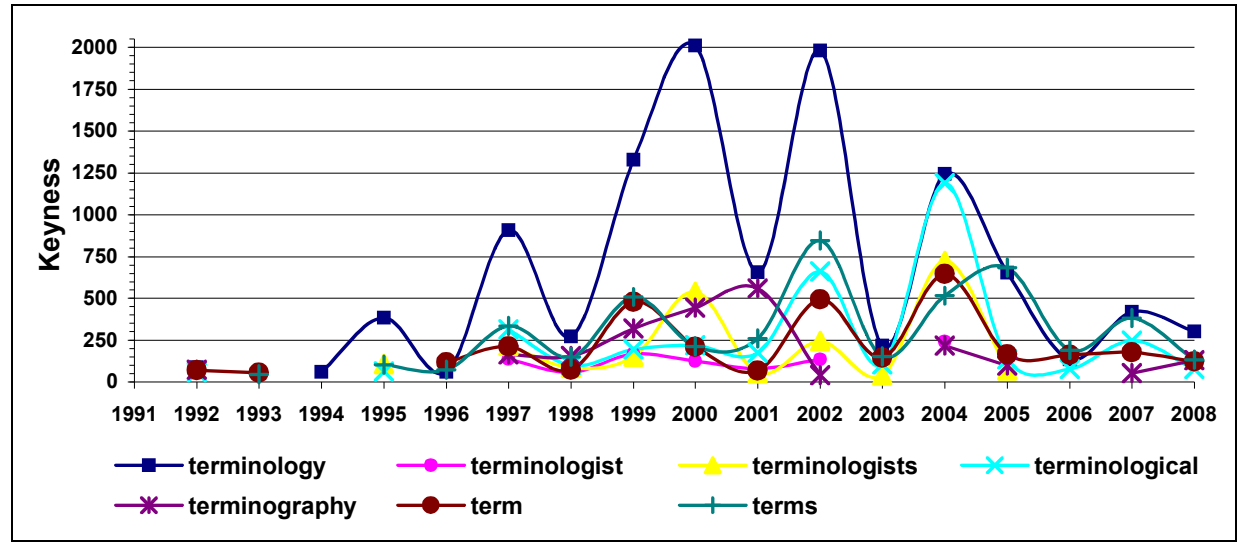

Figure 11: Keyness values for terminology etc. in each Lexikos issue

\subsubsection{Metalexicography}

In Section 3.2 above, we noted Lexikos's openness towards metalexicography. We are now in a position to analyse this aspect in more depth. Figure 12 plots the distribution of the general keywords concept(s), principle(s), scientific and theoretical. From the graph it is clear that the period 1999-2004 should be regarded as the most active. Focusing on lexicography itself, this is confirmed in Figures 13 through 15.

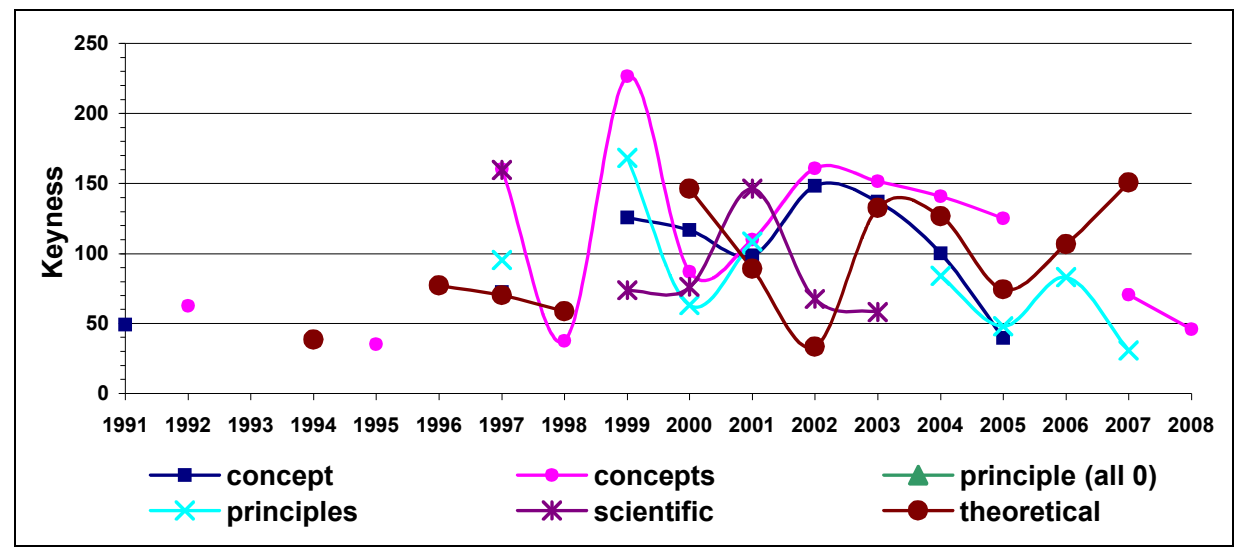

Figure 12: Keyness values for theoretical etc. in each Lexikos issue 


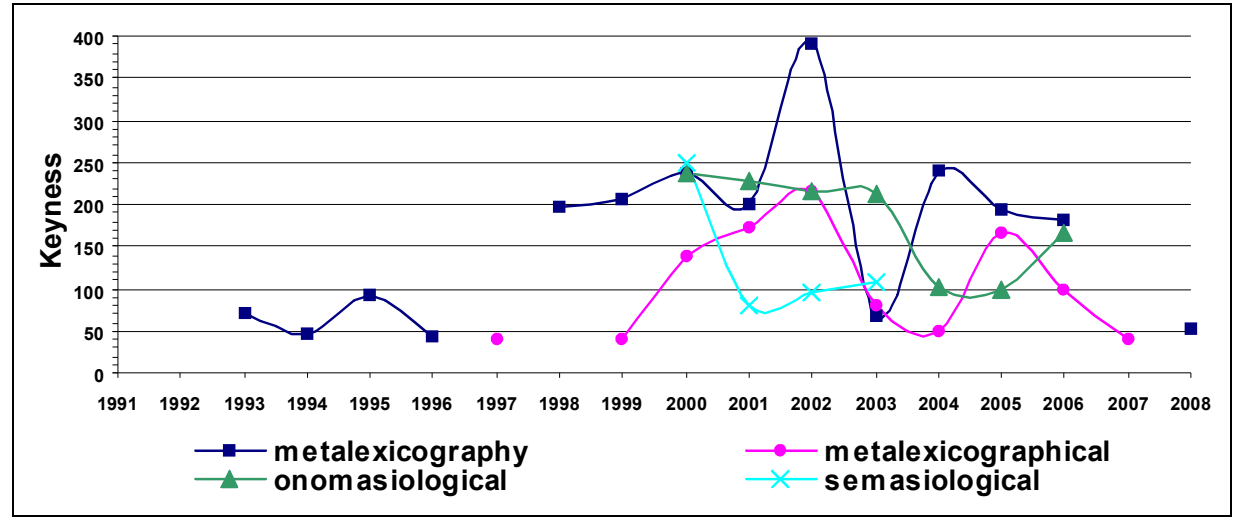

Figure 13: Keyness values for metalexicography etc. in each Lexikos issue

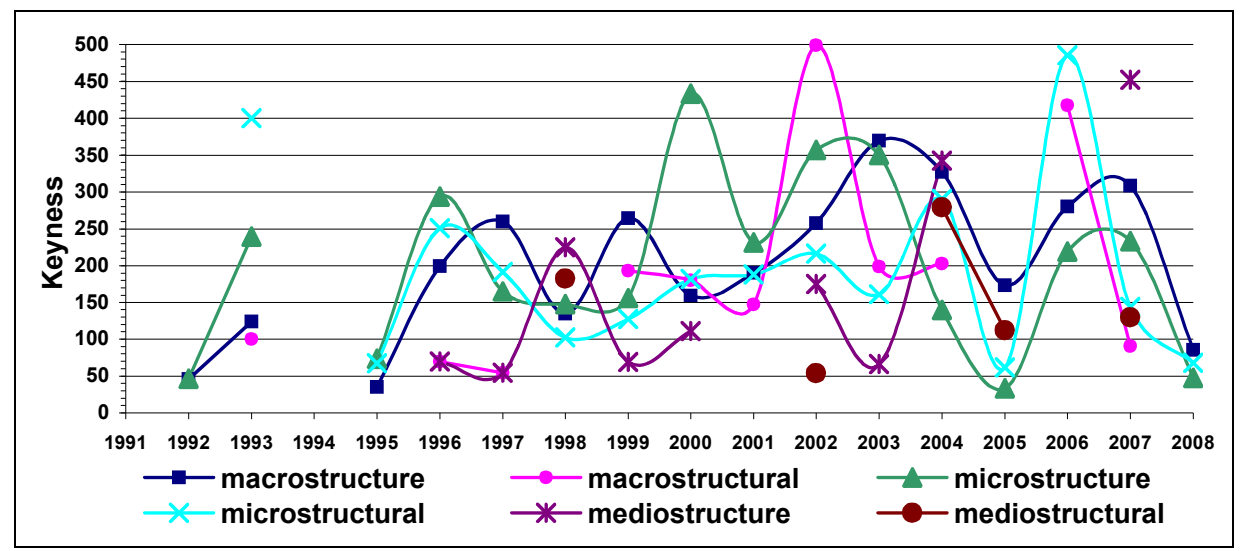

Figure 14: Keyness values for $x$-structure in each Lexikos issue

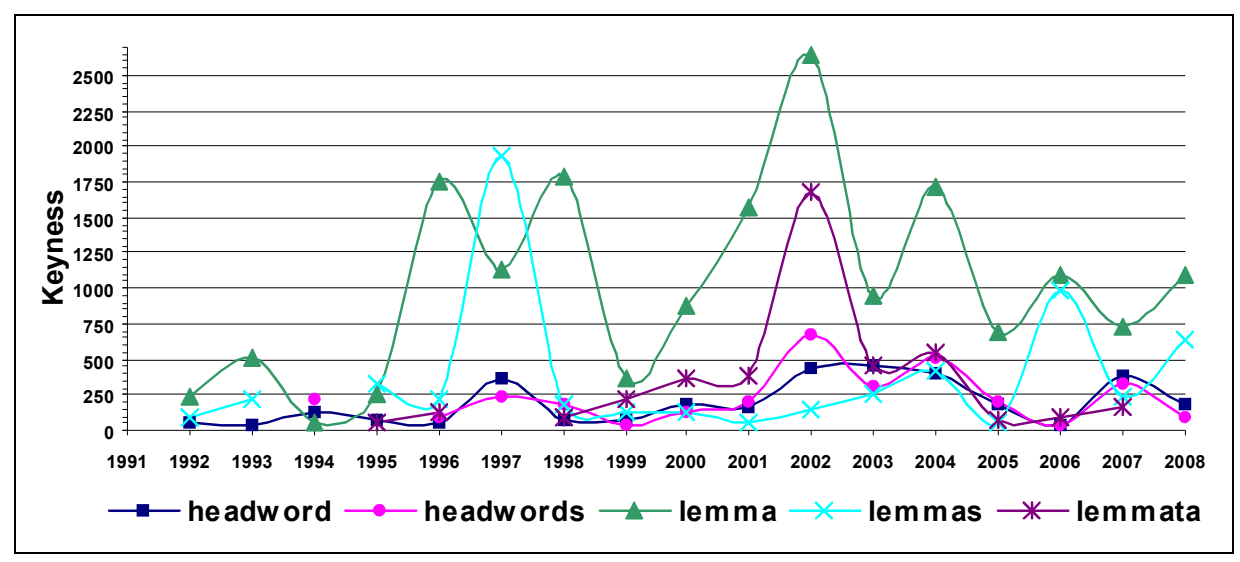

Figure 15: Keyness values for lemma etc. in each Lexikos issue 
In Figure 13, the terms metalexicography and metalexicographical are especially key for the period 2000-2005, while highly technical terms like onomasiological vs. semasiological also become key during that period. Figure 14 looks at where terms like macro-, micro- and mediostructure peak, which is roughly 2000-2004. In Figure 15, lastly, the common headword(s) is contrasted with the scientific lemma(s)/lemmata, which clearly indicates that the vast majority of the contributors to Lexikos indeed use field-specific terms. ${ }^{7}$ These results stand in sharp contrast to those found for IJL, where far fewer theoretical terms are found in the keyword lists.

\subsubsection{Polysemy and synonymy}

Figures 16 and 17 summarize the use of respectively polysemous and synonymous terms in Lexikos.

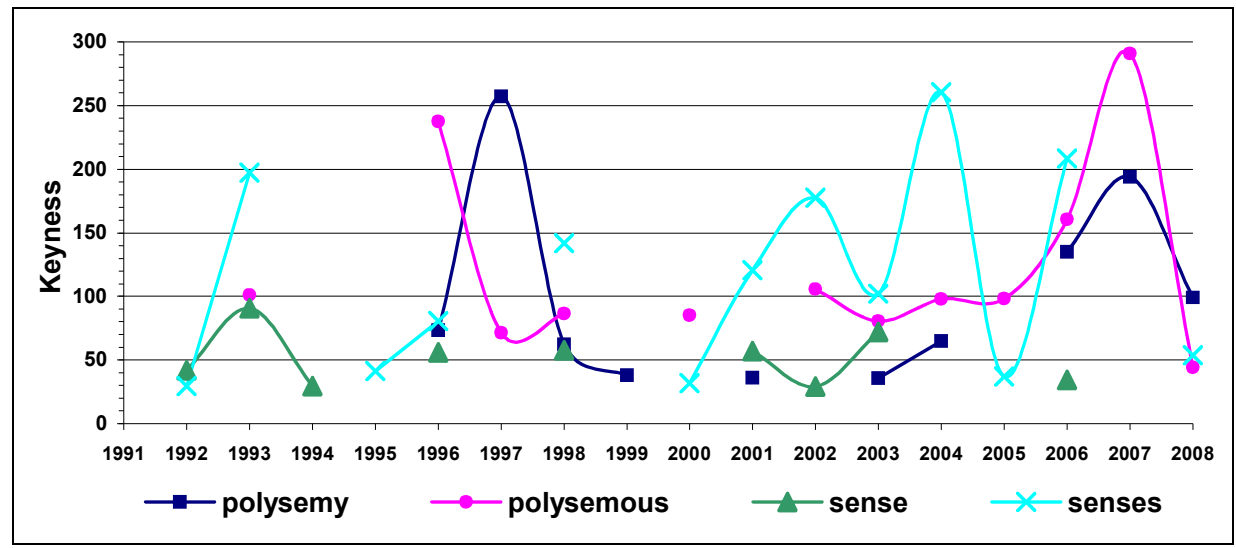

Figure 16: Keyness values for polysemy etc. in each Lexikos issue

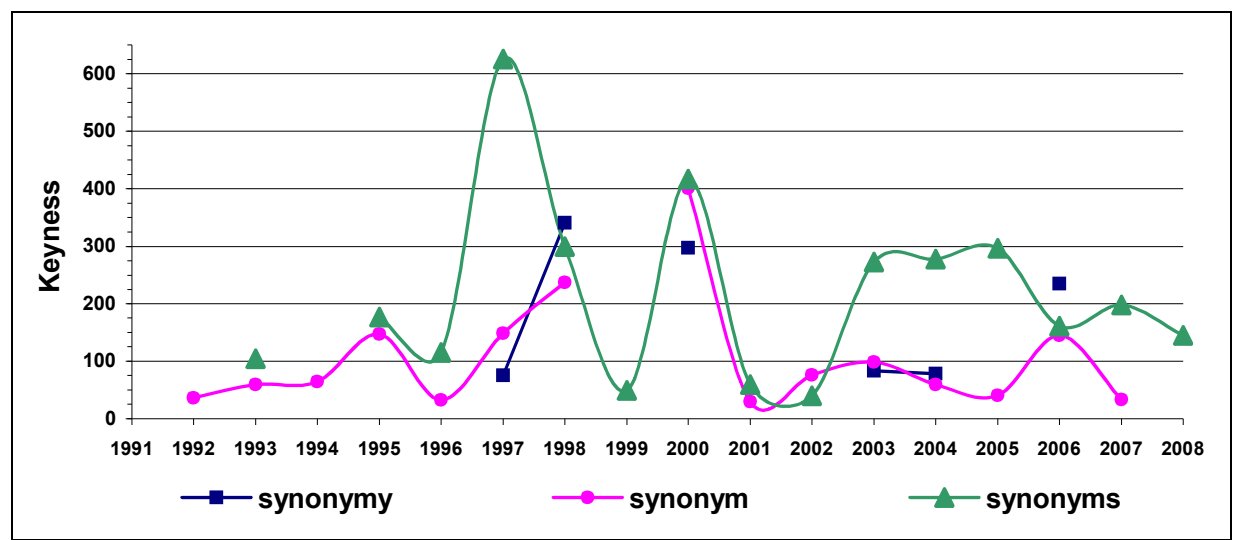

Figure 17: Keyness values for synonymy etc. in each Lexikos issue 
From Figures 16 and 17 one may conclude that polysemy and synonymy are (a) not typically treated together in metalexicographical discussions, and (b) not always at the centre of such discussions. Both these findings run against what one would have expected.

\subsubsection{Meaning, collocations, and examples vs. idioms/proverbs, and dialects/ slang}

While there are lexicographic topics for which one expects some kind of continuity, such as meaning, collocations or examples, others only appear sporadically, such as idioms and proverbs or dialects and slang. The difference can clearly be seen from Figures 18 through 22. Such graphs thus visualize where which topics are being discussed, and with which weighted frequency. In each of those graphs, peaks nonetheless pinpoint heightened activity.

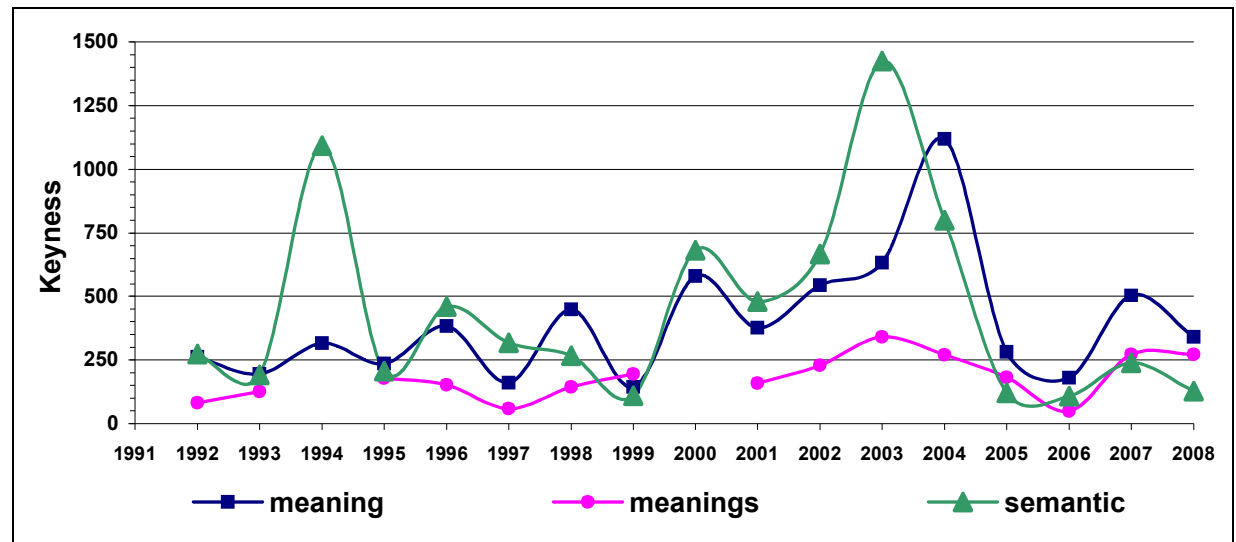

Figure 18: Keyness values for meaning(s) and semantic in each Lexikos issue

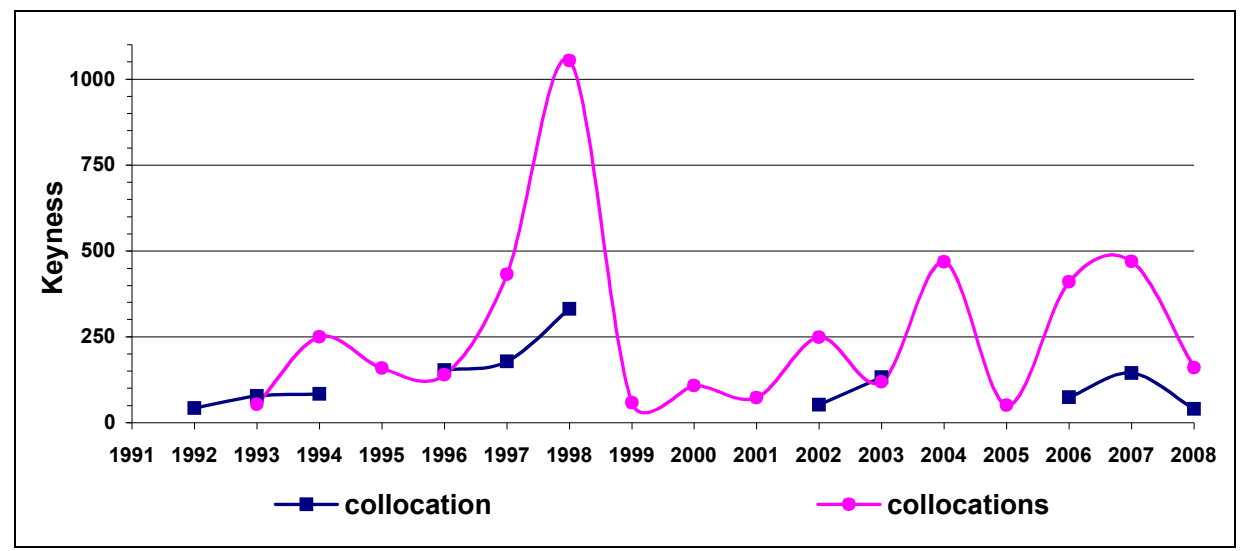

Figure 19: Keyness values for collocation(s) in each Lexikos issue 


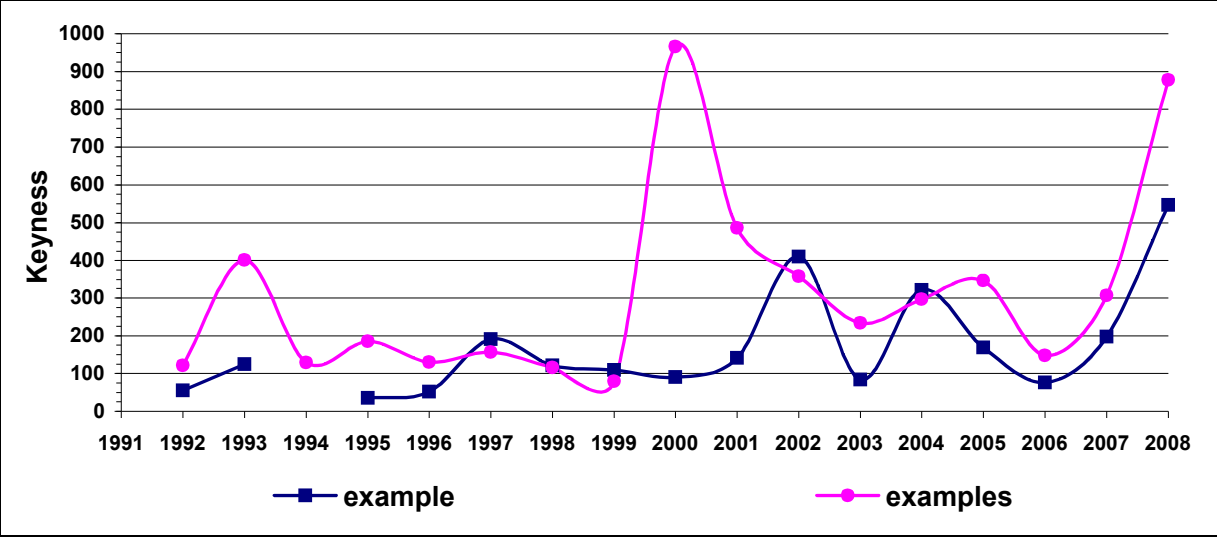

Figure 20: Keyness values for example(s) in each Lexikos issue

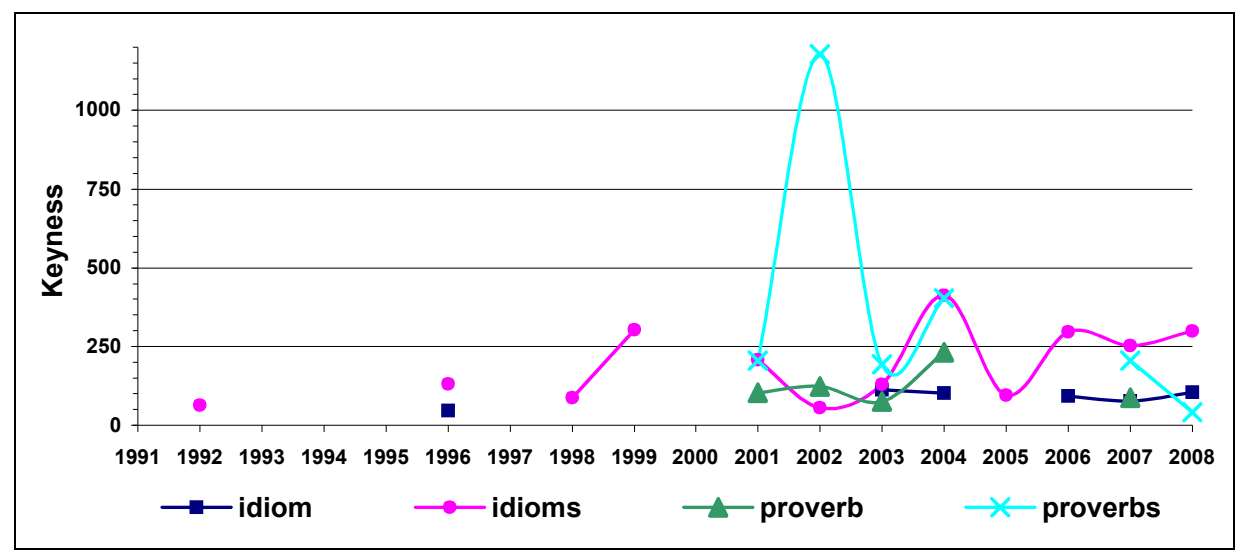

Figure 21: Keyness values for idiom(s) and proverb(s) in each Lexikos issue

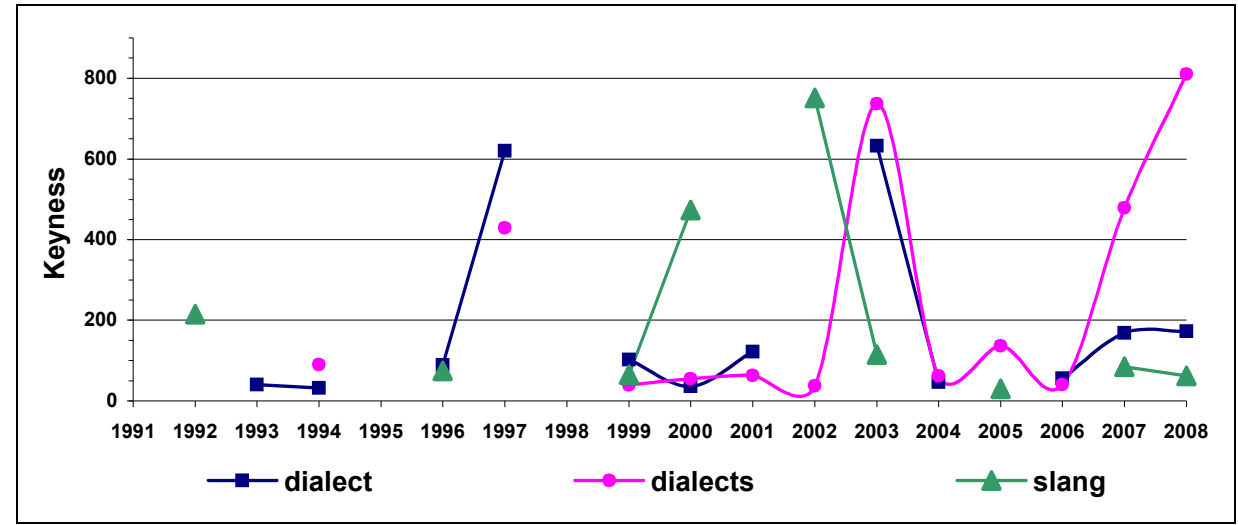

Figure 22: Keyness values for dialect(s) and slang in each Lexikos issue 


\subsubsection{The user perspective}

To conclude this section, one may also briefly look at the user perspective. While the high day of the user perspective was found to be the period 19972004 in IJL, Figures 23 and 24 indicate that that period is narrowed down in Lexikos to basically two years: 2001 and 2004 (recall the special section on 'Learners' Dictionaries' that was added in Volume 14, cf. Section 2.1 above).

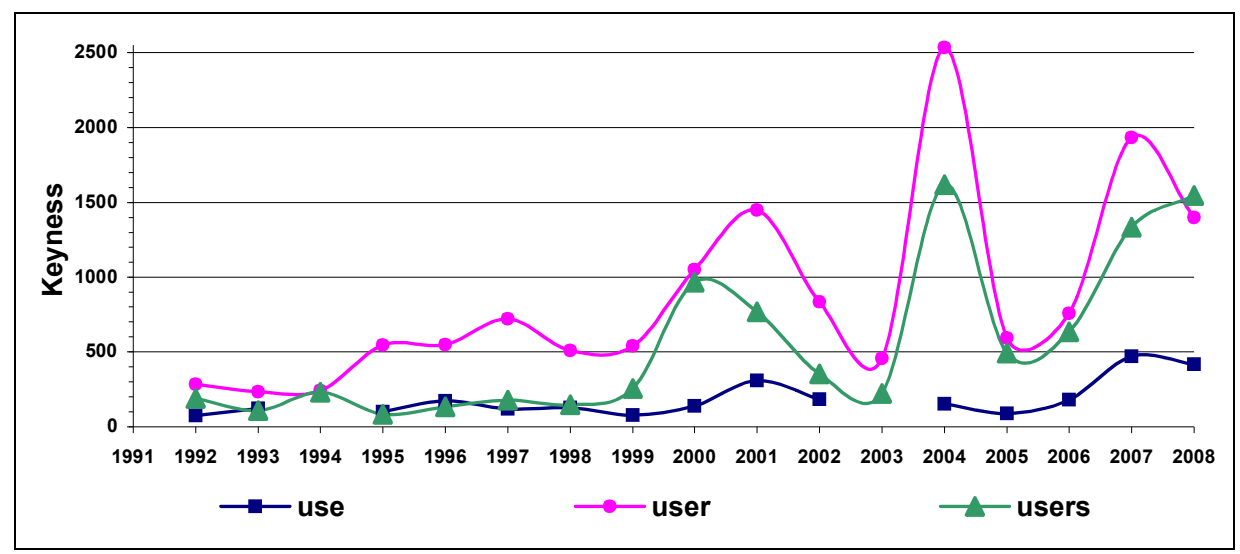

Figure 23: Keyness values for use and user(s) in each Lexikos issues

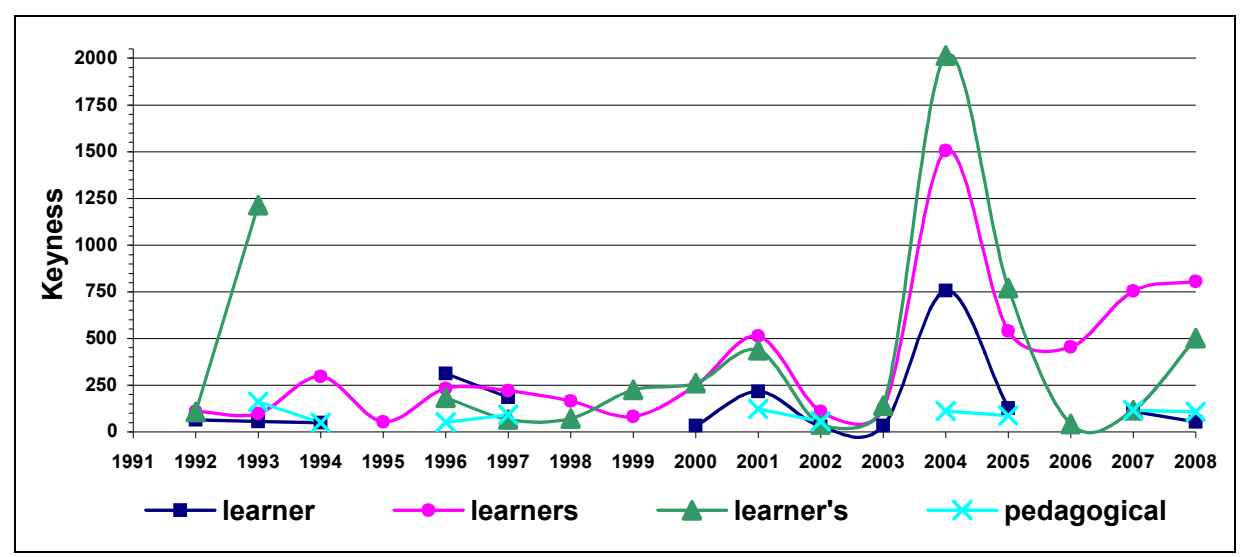

Figure 24: Keyness values for learner(s) etc. in each Lexikos issue

\section{Summary and discussion}

In this article an in-depth analysis was presented of both the publication details and the characteristic lexical items for the journal Lexikos from the first volume to the present. In Section 1 it was pointed out that Lexikos has become increasingly more professional with each new volume. Section 2 was devoted to an 
analysis of the Lexikos Metadata Database. It was shown that the number of pages as well as the number of contributions - averaging 366 pages and 30 contributions per volume - steadily rose over the years. English has become the main discourse language (currently stabilized at $70 \%$, on average $65 \%$ ), followed by Afrikaans (currently stabilized at $20 \%$, on average $26 \%$ ). Other languages used are German, French, and Dutch. About $44 \%$ of the contributions are articles, $4 \%$ are review articles, and $20 \%$ are book reviews. As many as $83 \%$ of the contributions are single-authored, $12 \%$ are joint efforts. A total of 260 scholars contributed to Lexikos during the first eighteen years, one third of them $(34 \%)$ more than once. Those repeat contributors are also 'faithful' in that their input is regular. Most repeat contributors moreover started publishing in Lexikos over the past few years, which bodes well for the future of Lexikos. About three quartes of the contributors (74\%) are based in Africa, $86 \%$ of those in South Africa. Within South Africa, 30\% are based in Pretoria and as many as $46 \%$ in Stellenbosch. In Pretoria, the most productive centre is the Department of African Languages at the University of Pretoria (33\%), while in Stellenbosch it is the Department of Afrikaans and Dutch at the University of Stellenbosch $(39 \%)$ and especially the Bureau of the WAT $(45 \%)$.

Some caution in interpreting the last set of results is in order. While it is undeniable that a very large percentage of the material published in Lexikos emanates from South Africa, the African reach and especially the interaction with the rest of Africa is larger than these statistics suggest. Firstly, through various cooperation agreements, students from the rest of Africa are enrolled at South African universities, where they obtain degrees in lexicography. The prime example here is the Department of Afrikaans and Dutch at the University of Stellenbosch, where several Gabonese students have obtained their PhDs over the past few years. Many of them published their results in Lexikos, using their South African affiliations while in South Africa. This is for example the case for Mavoungou, nr. 12 in Table 6. The same is true for PhD students from Namibia (for example Beyer, nr. 16 in Table 6). Secondly, success breeds success. Both Lexikos and AFRILEX can definitely be seen as South African lexicographic success stories, and as a result of their reputation, scholars now continue to visit South Africa, wishing to do their research in South Africa rather, sometimes even on South African languages (as is the case for the current writer).

Section 3 was devoted to an analysis of the Lexikos Corpus, more in particular that part containing all 355 English-language contributions which appeared in Lexikos to date, totalling 1744536 tokens and 65485 types. That corpus was partitioned in three sub-corpora (of 6 years each) as well as 18 subcorpora (i.e. per year), in order to study various trends across time (based on the keyness measure as compared with the BNC). With regard to dictionaries discussed in Lexikos, a rather stable picture was found, both in terms of number of keywords and keyness values. In contrast, the number of lexicographers competing for keyword status increases with time. Looking at the languages as 
objects of investigation, those were found to be overwhelmingly English and Afrikaans first, and biased towards the official South African languages second. Within the latter group, the order of attention is (a) Sotho languages (with especially Northern Sotho), (b) Nguni languages (with Zulu the most recent focus), (c) Venda, and lastly (d) Tsonga.

Seven key topic areas were also studied, the first being parts of speech, for which it was found that the list of word classes studied from a lexicographic point of view most definitely grows with the years in Lexikos. The second area was $n$-lingual lexicography, for which it was shown that bilingual lexicography is more popular than monolingual and multilingual lexicography in scholarly discussions. Thirdly, when it comes to terminology and terminography, a flurry of activity for the period 1997-2004 could be pinpointed. In a fourth section Lexikos was found to be highly theoretically oriented, certainly more than the International Journal of Lexicography, with the vast majority of the contributors using field-specific terms. Fifthly, for polysemy and synonymy the conclusions were that they are (a) not typically treated together in metalexicographical discussions, and (b) not always at the centre of such discussions. In a sixth section continuity was found for topics such as meaning, collocations or examples, while topics such as idioms and proverbs or dialects and slang are more sporadic. Lastly, attention to the user perspective in Lexikos was found to peak in the years 2001 and 2004.

Looking back, then, one cannot but be impressed by the achievements of Lexikos. One recognizes a healthy research culture, to which both lexicographers and metalexicographers contribute, on a variety of languages, in a variety of sub-disciplines. There is still a strong South African bias, however, which Lexikos as an adult should now shed.

\section{Acknowledgements}

Many thanks are due to Ms Riette Ruthven, who helped in assembling the Lexikos 1-10 material underlying the Lexikos Corpus. She managed to extract most data from legacy Word files, re-scanned the missing parts, and helped restoring diacritics. Volumes 11-17 were downloaded via the Sabinet Online service. Lexikos 18 was received directly as a single PDF file from the Bureau of the WAT.

\section{Endnotes}

1. Only very rarely is an article a reworked version of a published conference proceedings paper, such as Gouws (2001) vs. Gouws (2001a), or Mafela (2004) vs. Mafela (2005).

2. The percentage of editorial material is relatively high. This is so because all editorial material — written by the Lexikos Editor and the AFRILEX President - always appears in both Afrikaans and English. 
3. In calculating this, some of the names were collapsed: 'Potgieter, Liezl' with (née) 'Gouws, Liezl', and 'Nong, Salmina' with (née) 'Maepa, Salmina'.

4. $\quad$ See endnote 2.

5. For the calculation of keywords and associated keyness values, the log-likelihood statistic of WordSmith 4.0 was used, with the minimum keyword frequency set at 3 , and the maximum $\mathrm{p}$ value $=0.0000001$. See for more details on the extraction of keywords for lexicographic purposes, Taljard and De Schryver (2002).

6. As keyness values are sensitive to (sub-)corpus size, figures for six-year windows are not directly comparable to per-year figures.

7. As one anonymous adjudicator correctly pointed out, this statement assumes (since these are keyness values, not frequencies) that the lemmas [headword] and [lemma] are of equal frequency in general English / the BNC. This is indeed a risky assumption, but as it turns out, is true: In the lemmatized BNC, the occurrences are respectively 65 vs. 60

\section{References}

BNC World Edition. 2009. A 100 million word collection of samples of written and spoken language from a wide range of sources, designed to represent a wide cross-section of British English from the later part of the 20th century [online]. http://www.natcorp.ox.ac.uk/

De Schryver, G.-M. 1999. Bantu Lexicography and the Concept of Simultaneous Feedback, Some Preliminary Observations on the Introduction of a New Methodology for the Compilation of Dictionaries with Special Reference to a Bilingual Learner's Dictionary Cilubà-Dutch. Unpublished M.A. Dissertation. Ghent: Ghent University.

De Schryver, G.-M. 2009. A Few Words from AFRILEX. Lexikos 19: xiv-xv.

De Schryver, G.-M. 2009a. Bibliometrics in Lexicography. International Journal of Lexicography 22(4).

Du Plessis, J.C.M.D. 2008. Foreword. Lexikos 18: xi.

Gouws, R.H. 2001. Enhancing the Access Structure of Translation Dictionaries. Lee, S. (Ed.). 2001. ASIALEX 2001 Proceedings, Asian Bilingualism and the Dictionary: 77-83. Seoul: Yonsei University, Center for Linguistic Informatics Development.

Gouws, R.H. 2001a. The Use of an Improved Access Structure in Dictionaries. Lexikos 11: 101-111.

Harteveld, P. 1991. Foreword. Lexikos 1: xii-xiv.

Mafela, M.J. 2004. Bilingual Dictionary and Meaning Discrimination in Venda. Williams, G. and S. Vessier (Eds.). 2004. Proceedings of the Eleventh EURALEX International Congress, EURALEX 2004, Lorient, France, July 6-10, 2004: 501-509. Lorient: Université de Bretagne Sud, Faculté des Lettres et des Sciences Humaines.

Mafela, M.J. 2005. Meaning Discrimination in Bilingual Venda Dictionaries. Lexikos 15: 276-285.

Scott, M. 2009. WordSmith Tools [online]. http://www.lexically.net/wordsmith/

Taljard, E. and G.-M. de Schryver. 2002. Semi-automatic Term Extraction for the African Languages, with Special Reference to Northern Sotho. Lexikos 12: 44-74.

Web of Science. 2009. Provides researchers, administrators, faculty, and students with quick, powerful access to the world's leading citation databases. Authoritative, multidisciplinary content covers over 10000 of the highest impact journals worldwide [online]. http://apps. isiknowledge.com/ [subscription required]

Zgusta, L. 1993. Book Review: Harteveld, P., Ed. 1991. Lexikos. International Journal of Lexicography 6(4): 305-306. 
Addendum 1: Keywords and keyness values for Lexikos sub-corpus 1: 19911996

\begin{tabular}{|c|c|c|c|c|c|c|c|c|c|c|c|}
\hline \# & Keyword & Keyness & \# & Keyword & Keyness & \# & Keyword & Keyness & $\#$ & Keyword & Keyness \\
\hline 1 & DICTIONARY & 20062.88 & 76 & $\mathrm{Y}$ & 874.20 & 151 & BANTU & 441.47 & 226 & STANDARD & 298.10 \\
\hline 2 & AFRIKAANS & 11942.42 & 77 & X'S & 856.70 & 152 & SEMANTICS & 440.44 & 227 & ARTICLES & 295.97 \\
\hline 3 & DICTIONARIES & 9584.93 & 78 & ENTRY & 846.61 & $153 \mathrm{l}$ & METAFORMS & 438.95 & 228 & MALAYO & 292.63 \\
\hline 4 & ENGLISH & 8755.20 & 79 & ITEM & 832.12 & 154 & WÖRTERBUCH & 438.95 & 229 & WOORDENBOEK & 292.63 \\
\hline 5 & LANGUAGE & 6035.01 & 80 & BENG & 826.54 & $155 \mathrm{I}$ & PLURAL & 436.76 & 231 & LIT & 292.02 \\
\hline 6 & LEXICOGRAPHY & 5827.79 & 81 & TEXTUAL & 824.81 & 156 & CITATIONS & 433.80 & 230 & DEROGATORY & 289.50 \\
\hline 7 & LEXICAL & 4967.50 & 82 & TEXT & 823.28 & $157 \mathrm{I}$ & ET & 430.71 & 232 & MORPHEME & 288.87 \\
\hline 8 & AFRICAN & 4861.51 & 83 & MALAYU & 810.37 & 158 & ALLEX & 427.69 & 233 & OFFENSIVE & 287.93 \\
\hline 9 & LANGUAGES & 4281.88 & 84 & NIE & 808.10 & 159 & NEUTRAL & 425.71 & 234 & PREFIXES & 287.91 \\
\hline 10 & DUTCH & 3783.88 & 85 & EDS & 781.55 & 160 & $\mathrm{TL}$ & 423.08 & 235 & TERM & 287.78 \\
\hline 11 & LEXEMES & 3415.93 & 86 & MAGN & 780.80 & 1611 & REFERENCES & 420.90 & 236 & YA & 287.69 \\
\hline 12 & WORD & 3198.02 & 87 & HAUSMANN & 766.13 & 162 & STELLENBOSCH & 417.49 & 237 & MORPHEMES & 286.96 \\
\hline 13 & WAT & 3039.17 & 88 & ARTICLE & 752.27 & 1631 & NATIVE & 416.80 & 238 & STRUCTURE & 286.71 \\
\hline 14 & SOUTH & 2817.94 & 89 & LEARNERS & 744.21 & 164 & OXFORD & 411.96 & 239 & AFRIKA & 286.63 \\
\hline 15 & VERB & 2440.16 & 90 & LEMMAS & 734.55 & $166 \mathrm{I}$ & ENCYCLOPEDIC & 409.48 & 240 & TRANSLATING & 284.49 \\
\hline 16 & USAGE & 2435.08 & 91 & USERS & 721.04 & 165 & SYNONYMS & 405.81 & 241 & FURCHT & 281.38 \\
\hline 17 & LEXICOGRAPHICAL & 2427.54 & 92 & NACC & 694.09 & $168 \mathrm{l}$ & KLA & 405.18 & 242 & GROLL & 281.38 \\
\hline 18 & LEMMA & 2413.09 & 93 & AMERICAN & 692.96 & 1691 & LEMMATIC & 405.18 & 243 & KAMUSI & 281.38 \\
\hline 19 & LEXICOGRAPHER & 2357.89 & 94 & BLOUNT & 686.81 & 167 & ÜBERWINDEN & 405.18 & 244 & VERFLIEGEN & 281.38 \\
\hline 20 & SWAHILI & 2202.69 & 95 & AFK & 686.57 & $170 \mathrm{I}$ & PRONUNCIATION & 400.25 & 245 & EQUIVALENCE & 281.21 \\
\hline 21 & RACIST & 2112.91 & 96 & AFRILEX & 686.57 & 171 & GRAPHS & 395.77 & 246 & MORPHOLOGICAL & 280.59 \\
\hline 22 & SEMANTIC & 2043.33 & 97 & REFERENCE & 661.17 & 172 & BÖSCHUNG & 393.93 & 247 & ABBREVIATIONS & 280.26 \\
\hline 23 & NON & 2002.94 & 98 & FR & 648.36 & $173 \mathrm{I}$ & IPA & 390.51 & 248 & SLANG & 280.11 \\
\hline 24 & BILINGUAL & 1998.65 & 99 & EQUIVALENTS & 640.55 & $174 \mathrm{I}$ & IN & 390.49 & 249 & PHONETIC & 277.58 \\
\hline 25 & WORDS & 1919.72 & 100 & LINGUISTS & 635.97 & $175 \mathrm{I}$ & $\mathrm{DB}$ & 389.23 & 250 & EXAMPLE & 277.41 \\
\hline 26 & USER & 1799.97 & 101 & OCCURRENCE & 627.08 & 176 & TEXTS & 389.17 & 251 & NIGGER & 274.58 \\
\hline 27 & LEXICOGRAPHERS & 1791.22 & 102 & CONDENSATION & 624.27 & $177 \mathrm{I}$ & PREFIX & 387.42 & 252 & DISCUSSION & 273.04 \\
\hline 28 & VERBS & 1782.64 & 103 & EDITORIAL & 611.66 & 178 & ASHKENAZIC & 384.80 & 253 & DSYNTA & 270.12 \\
\hline 29 & LINGUISTIC & 1769.81 & 104 & USAGES & 600.86 & 179 & LEXICOGRAPHICA & 382.67 & 254 & LEXIKOGRAPHIE & 270.12 \\
\hline 30 & YIDDISH & 1664.82 & 105 & IS & 600.30 & 180 & WUT & 382.67 & 255 & OSSELTON & 270.12 \\
\hline 31 & ENTRIES & 1644.69 & 106 & STEM & 596.12 & 1811 & FORM & 378.27 & 256 & SCHÜREN & 270.12 \\
\hline 32 & LEXICOGRAPHIC & 1638.07 & 107 & MICROSTRUCTURAL & 590.54 & 182 & EQUIVALENT & 378.20 & 257 & DICTIONNAIRE & 270.04 \\
\hline 33 & CF & 1633.09 & 108 & MICROSTRUCTURE & 577.50 & 183 & ORTHOGRAPHIC & 374.30 & 258 & TONO & 269.36 \\
\hline 34 & AFRICA & 1628.05 & 109 & ANGST & 564.87 & 184 & $\mathrm{AL}$ & 367.56 & 259 & OED & 267.87 \\
\hline 35 & ETYMOLOGY & 1525.77 & 110 & REFLEXIVES & 562.76 & 1851 & ILLUSTRATIVE & 367.24 & 260 & CATEGORIES & 267.04 \\
\hline 36 & TRANSLATION & 1489.92 & 111 & BRANFORD & 559.64 & 186 & WNT & 360.16 & 261 & ELKE & 266.36 \\
\hline 37 & ITEMS & 1452.08 & 112 & UNIVERSITY & 550.47 & $187 \mathrm{~s}$ & SHONA & 358.27 & 262 & HABEN & 265.28 \\
\hline 38 & WOORDEBOEK & 1384.41 & 113 & LFS & 549.51 & 1881 & HOFFNUNG & 357.09 & 263 & PRESS & 264.49 \\
\hline 39 & ZULU & 1365.02 & 114 & TERMINOLOGY & 547.88 & $189 \mathrm{l}$ & MACROSTRUCTURE & 352.84 & 264 & AUSTRALIAN & 261.75 \\
\hline 40 & MEANING & 1359.95 & 115 & CORPORA & 547.11 & 190 & WÖRTERBÜCHER & 348.91 & 265 & PEDAGOGICAL & 260.47 \\
\hline 41 & CAPE & 1336.03 & 116 & MULTILINGUAL & 537.95 & 191 & ALPHABET & 344.36 & 266 & INDIGENOUS & 260.43 \\
\hline 42 & JEWISH & 1310.92 & 117 & MEANINGS & 537.46 & 192 & POLYSEMOUS & 343.40 & 267 & ONESELF & 260.39 \\
\hline 43 & NOUN & 1305.44 & 118 & LF & 529.46 & 193 & CONCISE & 342.38 & 268 & ÄRGER & 258.87 \\
\hline 44 & HARTMANN & 1301.68 & 119 & ORTHOGRAPHIES & 523.47 & 1941 & LABEL & 340.78 & 269 & DICTIONNAIRES & 258.87 \\
\hline 45 & CORPUS & 1266.75 & 120 & COLLOCATIONS & 523.05 & $195 \mathrm{l}$ & KISI & 337.65 & 270 & EMPFINDEN & 258.87 \\
\hline 46 & LEARNER'S & 1258.91 & 121 & $\begin{array}{l}\text { SPELLING } \\
\text { SPIN }\end{array}$ & 513.43 & 196 & GRAMMAR & 336.41 & 271 & ENTZÜCKEN & 258.87 \\
\hline 47 & MONOLINGUAL & 1229.53 & 122 & ORIGIN & 513.31 & $197 \mathrm{I}$ & EXPRESSIONS & 333.49 & 272 & ERREGEN & 258.87 \\
\hline 48 & NOUNS & 1209.48 & 123 & USED & 509.56 & $198 \mathrm{I}$ & FORMS & 331.60 & 273 & ILSON & 258.87 \\
\hline 49 & TAAL & 1188.01 & 124 & OF & 506.45 & 199 & NORTHEASTERN & 331.40 & 274 & JOOD & 258.87 \\
\hline 50 & AFRIKAANSE & 1181.81 & 125 & PRETORIA & 498.75 & 200 & COBUILD & 330.31 & 275 & MANIFESTABLE & 258.87 \\
\hline 51 & LINGUISTICS & 1173.62 & 126 & ZGUSTA & 495.23 & 201 & NIEMEYER & 328.64 & 276 & TWEETALIGE & 258.87 \\
\hline 52 & COMPILERS & 1169.18 & 127 & LEXICOGRAPHER'S & 495.19 & 2021 & HEADWORD & 328.39 & 277 & UNTERDRÜCKEN & 258.87 \\
\hline 53 & LEXEME & 1165.18 & 128 & EDITION & 491.29 & $203 \mathrm{I}$ & BEGEISTERUNG & 326.40 & 278 & VERSETZEN & 258.87 \\
\hline 54 & EMOTION & 1162.40 & 129 & SYNTACTIC & 483.07 & 2041 & PANIK & 326.40 & 279 & WECKEN & 258.87 \\
\hline 55 & GRAMMATICAL & 1154.34 & 130 & KISWAHILI & 480.59 & 205 & COLLOCATION & 325.44 & 280 & VOWEL & 257.64 \\
\hline 56 & ARABIC & 1151.52 & 131 & ETC & 479.51 & 206 & SENSES & 323.63 & 281 & SUCH & 256.82 \\
\hline 57 & BUREAU & 1149.35 & 132 & HOTTENTOT & 478.79 & 207 & NASAL & 323.29 & 282 & DATA & 255.94 \\
\hline 58 & XHOSA & 1144.14 & 133 & NADEN & 478.79 & $208 \mathrm{I}$ & INCLUSION & 321.69 & 283 & TERMS & 252.47 \\
\hline 59 & $\mathrm{ACC}$ & 1090.04 & 134 & MUSLIM & 478.49 & $209 \mathrm{I}$ & FEM & 317.87 & 284 & vs & 250.87 \\
\hline 60 & LEXIKOS & 1080.51 & 135 & LEXICON & 473.80 & $210 \mathrm{I}$ & EIFERSUCHT & 315.14 & 285 & LEGEN & 247.61 \\
\hline 61 & SPEAKERS & 1071.30 & 136 & GOUWS & 472.71 & 2111 & FÜHLEN & 315.14 & 286 & MEL'CUK & 247.61 \\
\hline 62 & NETHERLAND & 1057.53 & 137 & ISIXHOSA & 472.71 & 212 & GIVEN & 313.79 & 287 & NACHLASSEN & 247.61 \\
\hline 63 & DEFINITION & 1035.40 & 138 & USE & 471.46 & 213 & $\mathrm{SICH}$ & 312.65 & 288 & OTJIHERERO & 247.61 \\
\hline 64 & GEFÜHL & 1012.97 & 139 & ACHTUNG & 471.20 & $214 s$ & SYNONYM & 311.47 & 289 & SCHAM & 247.61 \\
\hline 65 & ORTHOGRAPHY & 985.06 & 140 & FREUDE & 467.72 & $215 \mathrm{l}$ & LOB & 310.39 & 290 & ÜBERKOMMEN & 247.61 \\
\hline 66 & WIEGAND & 984.95 & 141 & $\mathrm{BL}$ & 464.54 & 216 & THUS & 310.28 & 291 & LIEBE & 244.88 \\
\hline 67 & ED & 952.68 & 142 & TÜBINGEN & 461.46 & 217 & TARGET & 306.93 & 292 & HEADWORDS & 243.54 \\
\hline 68 & VOCABULARY & 947.04 & 143 & NTS & 459.10 & $218 \mathrm{I}$ & BEKOMMEN & 303.89 & 293 & CONDENSED & 242.32 \\
\hline 69 & EXAMPLES & 946.51 & 144 & LINGUIST & 454.15 & $219 \mathrm{I}$ & EURALEX & 303.89 & 294 & BRUIN & 240.94 \\
\hline 70 & SOTHO & 945.81 & 145 & LEARNER & 453.59 & $220 \mathrm{I}$ & LEIDENSCHAFT & 303.89 & 295 & GHANA & 239.69 \\
\hline 71 & INFORMATION & 944.23 & 146 & IDEOPHONES & 450.20 & 221 & $\mathrm{OR}$ & 303.39 & 296 & NGUNI & 239.39 \\
\hline 72 & DEFINITIONS & 922.19 & 148 & INL & 450.20 & 222 & COMPILATION & 302.90 & 297 & CATEGORY & 237.46 \\
\hline 73 & KAFFIR & 921.47 & 147 & KAFFER & 450.20 & 2231 & ECD & 300.46 & 298 & LABELS & 236.93 \\
\hline 74 & NDAT & 900.42 & 149 & NAMES & 443.92 & 2241 & ISO & 300.29 & 299 & BEDAUERN & 236.36 \\
\hline 75 & PHRASAL & 896.81 & 150 & EXETER & 443.51 & 225 & AS & 299.12 & 300 & MITLEID & 236.36 \\
\hline
\end{tabular}


Addendum 2: Keywords and keyness values for Lexikos sub-corpus 2: 19972002

\begin{tabular}{|c|c|c|c|c|c|c|c|c|c|c|c|}
\hline \# & Keyword & Keyness & \# & Keyword & Keyness & \# & Keyword & Keyness & \# & Keyword & Keyness \\
\hline 1 & DICTIONARY & 37222.13 & 76 & ITEMS & 1536.58 & 151 & ELECTRONIC & 783.27 & 226 & DEFINING & 538.12 \\
\hline 2 & DICTIONARIES & 19532.26 & 77 & BOHLALE & 1525.54 & 152 & MICROSTRUCTURAL & 779.39 & 227 & CONCEPT & 537.93 \\
\hline 3 & LANGUAGE & 13562.42 & 78 & EQUIVALENCE & 1521.71 & 153 & MEANINGS & 764.71 & 228 & LIST & 535.53 \\
\hline 4 & LEXICOGRAPHY & 11015.13 & 79 & AFRIKAANSE & 1515.44 & 154 & $\mathrm{AL}$ & 757.99 & 229 & PANSALB & 535.45 \\
\hline 5 & LANGUAGES & 8885.86 & 80 & NDEBELE & 1485.13 & 155 & REFERENCES & 756.41 & 231 & GABONESE & 530.05 \\
\hline 6 & DIE & 8761.30 & 81 & GRAMMATICAL & 1455.08 & 156 & KNOWLEDGE & 750.00 & 230 & SEMI & 528.63 \\
\hline 7 & AFRICAN & 7485.60 & 82 & TERM & 1410.82 & 157 & TONGUE & 749.67 & 232 & SMIT & 525.56 \\
\hline 8 & CORPUS & 7412.14 & 83 & WOORDEBOEKE & 1384.10 & 158 & CONCEPTS & 748.61 & 233 & PHRASES & 525.15 \\
\hline 9 & WIEGAND & 7095.03 & 84 & TERMINOLOGICAL & 1374.35 & 159 & LOANWORDS & 739.18 & 234 & DRC & 521.89 \\
\hline 10 & ENGLISH & 6987.90 & 85 & WIEGAND'S & 1353.79 & 160 & GABON & 738.47 & 235 & TEXTUAL & 521.63 \\
\hline 11 & VAN & 6791.82 & 86 & DEFINITION & 1347.76 & 161 & SUID & 737.50 & 236 & DUTCH & 519.55 \\
\hline 12 & LEMMA & 6682.36 & 87 & UNIVERSITY & 1344.69 & 162 & PLURAL & 734.68 & 237 & SETSWANA & 518.29 \\
\hline 13 & TERMINOLOGY & 6400.04 & 88 & XHOSA & 1335.53 & 163 & FIELD & 725.42 & 238 & NOORD & 515.43 \\
\hline 14 & WORD & 6174.76 & 89 & NOUNS & 1327.65 & 164 & DIALECT & 723.68 & 239 & RECHISHONA & 515.24 \\
\hline 15 & LEXICAL & 5329.38 & 90 & MPŠA & 1293.17 & 166 & STANDARD & 721.04 & 240 & TERMINOLOGIST & 515.24 \\
\hline 16 & AFRIKAANS & 5313.14 & 91 & SWAHILI & 1289.27 & 165 & GRUYTER & 716.85 & 241 & PARAPHRASE & 514.66 \\
\hline 17 & LEXICOGRAPHIC & 5216.82 & 92 & SYNONYMS & 1287.77 & 168 & MOSADI & 707.19 & 242 & CATEGORIES & 510.05 \\
\hline 18 & USER & 4914.39 & 93 & SCHRYVER & 1261.29 & 169 & DICTIONNAIRE & 706.04 & 243 & EXPLANATORY & 509.26 \\
\hline 19 & WORDS & 4630.34 & 94 & LEARNERS & 1247.80 & 167 & FORMS & 701.07 & 244 & LEKSIKOGRAFIESE & 505.14 \\
\hline 20 & SOTHO & 3946.56 & 95 & MICROSTRUCTURE & 1242.85 & 170 & $\mathrm{CB}$ & 699.17 & 245 & ONOMASIOLOGICAL & 505.14 \\
\hline 21 & TRANSLATION & 3693.35 & 96 & TERMINOGRAPHY & 1242.65 & 171 & ENCARTA & 697.09 & 246 & LINGUISTS & 498.46 \\
\hline 22 & BILINGUAL & 3542.47 & 97 & ET & 1242.16 & 172 & LEMMATIZATION & 697.09 & 247 & SPELLING & 497.15 \\
\hline 23 & HAUSA & 3424.94 & 98 & ALPHABETICAL & 1237.81 & 173 & TÜBINGEN & 697.09 & 248 & NAMELY & 495.55 \\
\hline 24 & WAT & 3318.27 & 99 & ORTHOGRAPHY & 1208.73 & 174 & INTERNET & 686.18 & 249 & WOORDE & 495.03 \\
\hline 25 & SEPEDI & 3212.81 & $100 \mathrm{H}$ & HEADWORDS & 1199.94 & 175 & ALBERTS & 682.21 & 250 & WÖRTERBÜCHER & 495.03 \\
\hline 26 & LINGUISTIC & 3160.48 & $101 \mathrm{~N}$ & NIE & 1164.97 & 176 & NA & 680.52 & 251 & MACQUARIE & 492.82 \\
\hline 27 & ARTICLE & 3079.72 & $102 \mathrm{~B}$ & $\mathrm{BA}$ & 1140.54 & 177 & CONSIDERATE & 677.78 & 252 & EDITION & 492.50 \\
\hline 28 & SHONA & 3058.44 & $103 \mathrm{~T}$ & TAAL & 1123.86 & 178 & COMPILED & 676.60 & 253 & SCIENTIFIC & 490.98 \\
\hline 29 & TEXT & 2955.75 & $104 \mathrm{~s}$ & SESOTHO & 1122.08 & 179 & SOURCE & 673.48 & 254 & FUNCTIONAL & 490.14 \\
\hline 30 & $\mathrm{CF}$ & 2710.90 & $105 \mathrm{P}$ & PROVERBS & 1106.09 & 180 & DIPUKU & 666.78 & 255 & STEM & 487.98 \\
\hline 31 & WOORDEBOEK & 2667.21 & $106 \mathrm{E}$ & ED & 1096.87 & 181 & GILLES & 653.54 & 256 & SEARCH & 487.81 \\
\hline 32 & LEXICOGRAPHICAL & 2641.68 & $107 \mathrm{C}$ & COPULATIVE & 1091.27 & 182 & AS & 652.44 & 257 & SENSES & 486.42 \\
\hline 33 & EQUIVALENTS & 2488.19 & $108 \mathrm{~S}$ & SUBLEXICAL & 1089.83 & 183 & WÖRTERBUCH & 646.58 & 258 & LA & 485.61 \\
\hline 34 & USERS & 2484.20 & $109 \mathrm{H}$ & HEADWORD & 1087.33 & 184 & ENTRY & 644.56 & 259 & COMPONENT & 483.39 \\
\hline 35 & SOUTH & 2450.55 & $110 \mathrm{~s}$ & SPECIFIC & 1087.08 & 185 & BERGENHOLTZ & 636.47 & 260 & OUTER & 483.31 \\
\hline 36 & INFORMATION & 2409.82 & $111 \mathrm{~A}$ & ACCESS & 1078.63 & 186 & EDITORS & 634.70 & 261 & GRAMMAR & 481.12 \\
\hline 37 & LEXICOGRAPHERS & 2374.74 & $112 \mathrm{I}$ & ITEM & 1062.15 & 187 & ZGUSTA & 626.37 & 262 & SAGER & 474.41 \\
\hline 38 & SEMANTIC & 2366.90 & $113 \mathrm{~s}$ & SA & 1060.79 & 188 & KEYWORDS & 623.40 & 263 & VARIOUS & 473.96 \\
\hline 39 & TEXTS & 2346.14 & $114 \mathrm{~V}$ & VERBS & 1054.38 & 189 & ISIXHOSA & 616.27 & 264 & SEMANTICALLY & 473.43 \\
\hline 40 & CORPORA & 2335.47 & $115 \mathrm{~s}$ & SLANG & 1042.87 & 190 & REGARD & 609.50 & 265 & $\mathrm{GE}$ & 472.78 \\
\hline 41 & VERB & 2335.04 & $116 \mathrm{E}$ & EXAMPLE & 1011.57 & 191 & SINGULAR & 609.03 & 266 & DESCRIPTIVE & 470.10 \\
\hline 42 & LEXICOGRAPHER & 2270.21 & $117 \mathrm{~s}$ & STELLENBOSCH & 1005.08 & 192 & ISIZULU & 606.17 & 267 & TERMINOLOGIE & 465.12 \\
\hline 43 & NOUN & 2218.57 & $118 \mathrm{~N}$ & MACROSTRUCTURE & 1000.16 & 193 & LEXEMES & 603.77 & 268 & ALLEX & 464.73 \\
\hline 44 & LEXIKOS & 2212.56 & $119 \mathrm{~F}$ & FRANÇAIS & 990.08 & 194 & AFRIKA & 602.14 & 269 & MEDIOSTRUCTURE & 464.73 \\
\hline 45 & TERMS & 2187.85 & $120 \mathrm{C}$ & COPYRIGHT & 972.04 & 195 & NIEMEYER & 602.10 & 270 & METALEXICOGRAPHICAL & 464.73 \\
\hline 46 & MONOLINGUAL & 2158.57 & $121 \mathrm{C}$ & COMPILERS & 959.51 & 196 & KRIEL & 599.05 & 271 & COLLOCATION & 462.68 \\
\hline 47 & MEANING & 2142.08 & $122 \mathrm{~s}$ & STRUCTURE & 956.05 & 197 & FREQUENCY & 595.98 & 272 & PRESENTED & 459.78 \\
\hline 48 & $\mathrm{KA}$ & 2138.15 & $123 \mathrm{~L}$ & LEARNER'S & 955.96 & 198 & HARTMANN & 592.92 & 273 & GROOT & 458.70 \\
\hline 49 & GOUWS & 2121.63 & $124 \mathrm{C}$ & CONSONANT & 949.92 & 199 & TYPES & 591.36 & 274 & TECHNICAL & 458.32 \\
\hline 50 & PRETORIA & 2114.45 & $125 \mathrm{~T}$ & TERMINOLOGISTS & 949.67 & 200 & IDIOMS & 589.38 & 275 & NORTHERN & 456.66 \\
\hline 51 & LEMMATA & 2107.06 & $126 \mathrm{E}$ & ENCYCLOPEDIC & 933.89 & 201 & CROSS & 588.67 & 276 & IN & 455.25 \\
\hline 52 & EDS & 2058.02 & $127 \mathrm{~N}$ & METALEXICOGRAPHY & 929.46 & 202 & MANTŠU & 585.96 & 277 & TRANSLATIONS & 454.35 \\
\hline 53 & TARGET & 2057.42 & $128 \mathrm{~L}$ & USE & 929.07 & 203 & TARP & 585.90 & 278 & $\begin{array}{l}\text { PRINCIPLES } \\
\text { PRIN }\end{array}$ & 454.32 \\
\hline 54 & LEXICON & 2010.31 & $129 \mathrm{~L}$ & LEXIKOGRAPHIE & 919.36 & 204 & NON & 585.67 & 279 & VENDA & 454.28 \\
\hline 55 & LEMMAS & 2004.32 & $130 \mathrm{P}$ & PROJECT & 915.25 & 205 & SYNONYMY & 583.33 & 280 & SENTENCES & 452.24 \\
\hline 56 & AFRICA & 1954.78 & $131 \mathrm{~L}$ & DSAE & 909.25 & 206 & SEMANTICS & 581.43 & 281 & ENCYCLOPAEDIC & 451.08 \\
\hline 57 & EXAMPLES & 1954.06 & $132 \mathrm{Y}$ & YA & 897.54 & 207 & CULTURAL & 578.34 & 282 & ETYMOLOGY & 451.08 \\
\hline 58 & ARTICLES & 1828.75 & $133 \mathrm{I}$ & INDIGENOUS & 889.38 & 208 & ABBREVIATIONS & 576.14 & 283 & FEEDBACK & 450.86 \\
\hline 59 & REFERENCE & 1806.51 & $134 \mathrm{~A}$ & ARTIKEL & 889.05 & 209 & AFRIKATALE & 575.86 & 284 & THOUGHTFUL & 449.75 \\
\hline 60 & USAGE & 1777.37 & $135 \mathrm{C}$ & $\mathrm{OF}$ & 880.04 & 210 & CLUVER & 575.86 & 285 & NICHE & 445.59 \\
\hline 61 & VOCABULARY & 1774.09 & $136 \mathrm{~A}$ & ARABIC & 879.79 & 211 & DURAMAZWI & 575.86 & 286 & KONERDING & 444.52 \\
\hline 62 & COMPILATION & 1714.60 & $137 \mathrm{~L}$ & LSP & 869.89 & 212 & ORDERING & 574.86 & 287 & ISN & 444.37 \\
\hline 63 & SPEAKERS & 1688.41 & $138 \mathrm{C}$ & COBUILD & 850.31 & 213 & MULTI & 567.96 & 288 & ENCYCLOPEDIA & 442.46 \\
\hline 64 & NICHING & 1677.09 & $139 \mathrm{~L}$ & DATA & 836.42 & 214 & ALSO & 562.00 & 289 & SWEDISH & 442.12 \\
\hline 65 & PRINSLOO & 1665.49 & $140 \mathrm{~B}$ & BANTU & 834.20 & 215 & RESEARCH & 559.41 & 290 & ACCORDING & 441.38 \\
\hline 66 & ZULU & 1648.46 & $141 \mathrm{~L}$ & LEKSIKOGRAFIE & 808.22 & 216 & LOUW & 557.01 & 291 & BUSINESS & 440.43 \\
\hline 67 & MULTILINGUAL & 1641.82 & $142 \mathrm{~N}$ & MACROSTRUCTURAL & 808.22 & 217 & DIALECTS & 555.02 & 292 & PLURALS & 440.21 \\
\hline 68 & COLLOCATIONS & 1631.31 & $143 \mathrm{E}$ & EQUIVALENT & 808.09 & 218 & PREFIX & 549.19 & 293 & THEREFORE & 439.82 \\
\hline 69 & DEFINITIONS & 1606.27 & $144 \mathrm{C}$ & COPULATIVES & 798.12 & 219 & SL & 545.88 & 294 & NEEDS & 439.36 \\
\hline 70 & $\mathrm{KE}$ & 1597.31 & $145 \mathrm{~s}$ & SYNONYM & 796.57 & 220 & INL & 545.55 & 295 & REFERENCING & 438.69 \\
\hline 71 & AFRILEX & 1596.26 & $146 \mathrm{~L}$ & USED & 795.13 & 221 & LOUWRENS & 545.55 & 296 & LEMMATISATION & 436.90 \\
\hline 72 & MORUTIŠI & 1586.16 & $148 \mathrm{r}$ & NASAL & 792.15 & 222 & WYK & 541.63 & 297 & TREATMENT & 436.57 \\
\hline 73 & ENTRIES & 1579.21 & $147 \mathrm{I}$ & IS & 791.62 & 223 & PRONUNCIATION & 538.62 & 298 & KAF & 434.94 \\
\hline 74 & LINGUISTICS & 1558.84 & $149 \mathrm{E}$ & ETC & 789.05 & 224 & DGC & 538.35 & 299 & SEGMENT & 434.49 \\
\hline 75 & HAUSMANN & 1543.78 & $150 \mathrm{C}$ & CILUBȦ & 788.02 & 225 & ROM & 538.23 & 300 & VERKLARENDE & 434.42 \\
\hline
\end{tabular}


Addendum 3: Keywords and keyness values for Lexikos sub-corpus 3: 20032008

\begin{tabular}{|c|c|c|c|c|c|c|c|c|c|c|c|}
\hline \# & Keyword & Keyness [F & \# & Keyword & Keyness & $\#$ & Keyword & Keyness & $\#$ & Keyword & Keyness \\
\hline 1 & DICTIONARY & 60677.92 & 76 & SETSWANA & 1778.25 & $151 \mathrm{~s}$ & SCHOLTZ & 983.35 & 226 & HARARE & $\begin{array}{l}697.04 \\
\end{array}$ \\
\hline 2 & DICTIONARIES & 34268.95 & 77 & FRANÇAIS & 1771.51 & $152 \mathrm{I}$ & ISIXHOSA & 982.02 & 227 & MEDIOSTRUCTURE & 693.19 \\
\hline 3 & LANGUAGE & 22342.33 & 78 & KA & 1759.05 & $153 \mathrm{~A}$ & ADJ & 981.19 & 228 & SPOKEN & 691.46 \\
\hline 4 & LEXICOGRAPHY & 16604.31 & 79 & USAGE & 1737.13 & $154 \mathrm{~s}$ & SUFFIX & 980.06 & 229 & DEUTSCH & 690.33 \\
\hline 5 & LANGUAGES & 11389.05 & 80 & WOORDEBOEKE & 1723.37 & $155 \mathrm{I}$ & DEFINITIONAL & 973.51 & 231 & HAUSA & 685.63 \\
\hline 6 & ENGLISH & 9489.79 & 81 & ITEM & 1678.11 & $156 \mathrm{I}$ & LEKSIKOGRAFIE & 972.39 & 230 & EVALUATION & 684.54 \\
\hline 7 & LEXICOGRAPHIC & 8408.29 & 82 & INTERNET & 1649.28 & $157 \mathrm{C}$ & COMPILERS & 971.13 & 232 & BOSMAN & 683.80 \\
\hline 8 & SHONA & 8319.34 & 83 & STELLENBOSCH & 1641.89 & $158 \mathrm{c}$ & GRAMMAR & 968.81 & 233 & SVEN & 683.58 \\
\hline 9 & CORPUS & 8222.76 & 84 & GABON & 1631.54 & $159 \mathrm{~F}$ & FREQUENCY & 962.22 & 234 & EENTALIGE & 683.56 \\
\hline 10 & NDEBELE & 7895.39 & 85 & ORTHOGRAPHY & 1628.97 & $160 \mathrm{I}$ & LEXIKOGRAPHIE & 953.14 & 235 & MACROSTRUCTURAL & 683.56 \\
\hline 11 & USER & 7256.95 & 86 & EQUIVALENCE & 1626.88 & $161 s$ & SHANGANI & 953.14 & 236 & CROSS & 680.86 \\
\hline 12 & BILINGUAL & 6939.91 & 87 & ISN & 1624.42 & $162 s$ & SPELLING & 949.29 & 237 & CAPE & 680.60 \\
\hline 13 & LEXICAL & 6218.81 & 88 & TÜBINGEN & 1617.46 & 163 & YA & 944.02 & 238 & FIELD & 674.58 \\
\hline 14 & AFRIKAANS & 6101.93 & 89 & NON & 1614.95 & 164 & TSHIVENDA & 943.51 & 239 & TERMINOLOGISTS & 673.93 \\
\hline 15 & WORD & 6093.01 & 90 & AFRICA & 1570.08 & 166 & CULTURE & 934.00 & 240 & KISWAHILI & 669.92 \\
\hline 16 & WORDS & 5703.51 & 91 & SA & 1569.55 & $165 \mathrm{I}$ & DIALECT & 926.54 & 241 & PREFIX & 665.35 \\
\hline 17 & AFRICAN & 5608.01 & 92 & ET & 1569.43 & 168 & GRUYTER & 913.13 & 242 & COPULATIVE & 655.69 \\
\hline 18 & USERS & 5540.67 & 93 & LIST & 1545.90 & $169 \mathrm{P}$ & ADJECTIVES & 912.92 & 243 & NIENABER & 655.69 \\
\hline 19 & MONOLINGUAL & 5325.01 & 94 & AFRIKAANSE & 1530.81 & $167 \mathrm{I}$ & INDIGENOUS & 906.86 & 244 & HÜLLEN & 654.68 \\
\hline 20 & LEXICOGRAPHERS & 5118.73 & 95 & NIEMEYER & 1529.75 & $170 \mathrm{I}$ & LEARNER & 905.73 & 245 & VERBAL & 651.68 \\
\hline 21 & LEMMA & 5052.34 & 96 & HARTMANN & 1518.58 & $171 s$ & SEPEDI & 905.00 & 246 & TREATMENT & 649.34 \\
\hline 22 & TEXT & 4614.96 & 97 & TSHWANELEX & 1482.67 & $172 \mathrm{~N}$ & MICROSTRUCTURAL & 904.76 & 247 & NA & 642.26 \\
\hline 23 & SOTHO & 4607.16 & 98 & TERMINOLOGICAL & 1481.61 & $173 \mathrm{I}$ & LEMMATISATION & 900.28 & 248 & COMMUNICATION & 638.75 \\
\hline 24 & TRANSLATION & 4161.60 & 99 & NOUN & 1481.39 & $174 \mathrm{~F}$ & ETYMOLOGICAL & 898.83 & 249 & IS & 638.30 \\
\hline 25 & ARTICLE & 4062.62 & 100 & TAAL & 1462.62 & $175 \mathrm{I}$ & НTTP & 895.37 & 250 & PRESCRIPTIVE & 634.44 \\
\hline 26 & LEXICOGRAPHICAL & 3968.11 & 101 & OUTER & 1459.17 & $176 \mathrm{r}(\mathrm{r})$ & YILUMBU & 895.37 & 251 & RESEARCH & 628.99 \\
\hline 27 & LEXICOGRAPHER & 3895.24 & 102 & COLLOCATIONS & 1441.60 & $177 \mathrm{r}$ & PRONUNCIATION & 892.31 & 252 & POLYSEMOUS & 628.43 \\
\hline 28 & LEARNERS & 3806.67 & 1031 & PHAROS & 1415.66 & $178 \mathrm{I}$ & LEKSIKOGRAFIESE & 885.74 & 253 & MAIOR & 627.43 \\
\hline 29 & LINGUISTIC & 3735.64 & 104 & VENDA & 1409.96 & $179 \mathrm{I}$ & EXPRESSIONS & 884.43 & 254 & LA & 627.17 \\
\hline 30 & TEXTS & 3717.04 & $105 \mathrm{I}$ & DURAMAZWI & 1396.02 & $180 \mathrm{~F}$ & ENTRY & 883.62 & 255 & ISICHAZAMAZWI & 625.79 \\
\hline 31 & EQUIVALENTS & 3552.15 & 1061 & HEADWORD & 1383.63 & $181 \mathrm{~A}$ & ADJECTIVE & 870.45 & 256 & INTERLINGUAL & 625.04 \\
\hline 32 & REFERENCE & 3425.34 & 107 & NIE & 1380.57 & $182 \mathrm{~F}$ & RECHISHONA & 866.49 & 257 & SUBLEXICAL & 625.04 \\
\hline 33 & GOUWS & 3321.64 & $108 \mathrm{l}$ & IDIOMS & 1332.29 & $183 \mathrm{I}$ & LSP & 866.42 & 258 & SENSES & 622.08 \\
\hline 34 & ONLINE & 3174.96 & 109 & GRAMMATICAL & 1328.31 & $184 \mathrm{I}$ & INCLUSION & 862.09 & 259 & ELECTRONIC & 621.15 \\
\hline 35 & SCHRYVER & 3163.63 & $110^{\prime}$ & TERM & 1327.90 & 185 & THESE & 859.80 & 260 & ZIMBABWEAN & 618.98 \\
\hline 36 & WIEGAND & 3051.72 & 1111 & MEANINGS & 1321.60 & $186 s$ & SEMANTICS & 855.74 & 261 & INFLECTIONAL & 618.57 \\
\hline 37 & SWAHILI & 3051.10 & 112 & EXAMPLE & 1314.65 & $187 \mathrm{Z}$ & ZGUSTA & 847.23 & 262 & $\mathrm{x}$ & 616.54 \\
\hline 38 & SESOTHO & 3029.74 & 113 & ADVERBS & 1314.56 & 188 & TYPES & 845.42 & 263 & YIPUNU & 616.17 \\
\hline 39 & WOORDEBOEK & 2994.28 & 114 & USE & 1297.21 & $189 \mathrm{~N}$ & MICROSTRUCTURE & 844.61 & 264 & CRITERIA & 611.04 \\
\hline 40 & LEXIKOS & 2965.39 & 115 & TARGET & 1286.53 & $190 \mathrm{C}$ & OF & 839.19 & 265 & TRILINGUAL & 608.26 \\
\hline 41 & MEANING & 2920.72 & 116 & SPECIFIC & 1270.07 & 191 & COMPILING & 835.00 & 266 & MAROLE & 606.54 \\
\hline 42 & LEARNER'S & 2912.65 & $117 \mathrm{I}$ & DEFINITION & 1250.81 & $192 \mathrm{~A}$ & ALPHABETICAL & 834.15 & 267 & WÖRTERBÜCHER & 606.54 \\
\hline 43 & WAT & 2895.51 & 118 & SOUTH & 1239.26 & $193 \mathrm{C}$ & $\mathrm{CL}$ & 830.74 & 268 & EDITORS & 606.11 \\
\hline 44 & EDS & 2797.59 & 119 & SYNONYMS & 1234.83 & $194 \mathrm{I}$ & LONGMAN & 829.72 & 269 & NGUNI & 605.85 \\
\hline 45 & ITEMS & 2712.20 & 120 & ARTIKEL & 1232.34 & $195 \mathrm{H}$ & PRESENTED & 826.68 & 270 & ETYMOLOGY & 603.59 \\
\hline 46 & TERMINOLOGY & 2686.55 & 1211 & HESSELING & 1232.34 & $196 \mathrm{I}$ & PHONETIC & 824.18 & 271 & BASED & 601.95 \\
\hline 47 & COMPILATION & 2645.66 & 1221 & HEADWORDS & 1221.03 & $197 \mathrm{~F}$ & PRON & 820.91 & 272 & PRESENTATION & 601.39 \\
\hline 48 & VOCABULARY & 2605.56 & $123 \mathrm{I}$ & NOUNS & 1219.52 & $198 \mathrm{~F}$ & EURALEX & 818.35 & 273 & TOIT & 599.28 \\
\hline 49 & DATA & 2571.41 & $124 \mathrm{I}$ & REFERENCES & 1217.97 & $199 \mathrm{C}$ & CULTURAL & 809.36 & 274 & AS & 598.02 \\
\hline 50 & DEFINITIONS & 2558.94 & $125 \mathrm{I}$ & PHILIPPSON & 1213.09 & $200 \mathrm{~N}$ & MAVOUNGOU & 808.72 & 275 & GA & 596.57 \\
\hline 51 & LEBOA & 2512.87 & $126 \mathrm{I}$ & FORMS & 1192.56 & $201 \mathrm{r}$ & KEYWORDS & 808.70 & 276 & FOREIGN & 593.24 \\
\hline 52 & SEMANTIC & 2478.52 & 127 & VERBS & 1191.18 & $202 \mathrm{~F}$ & REGARD & 793.71 & 277 & DANISH & 591.96 \\
\hline 53 & GABONESE & 2472.23 & 128 & MACROSTRUCTURE & 1189.81 & 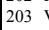 & VARIANTS & 791.83 & 278 & ACCESS & 587.32 \\
\hline 54 & BERGENHOLTZ & 2464.73 & $129 \mathrm{I}$ & LEXICON & 1188.27 & $204 \mathrm{~F}$ & EDITION & 787.19 & 279 & SHOULD & 585.16 \\
\hline 55 & ZULU & 2401.48 & $130 \mathrm{I}-\mathrm{l}$ & EQUIVALENT & 1180.09 & $205 \mathrm{r}$ & KHWE & 779.84 & 280 & LINGUISTS & 585.06 \\
\hline 56 & INFORMATION & 2372.10 & 131 & USED & 1175.08 & $206 \mathrm{I}$ & LEMMATIZATION & 760.58 & 281 & ZEZURU & 577.66 \\
\hline 57 & ENTRIES & 2360.37 & 132 & $\mathrm{AL}$ & 1175.01 & 207 & TWEETALIGE & 760.58 & 282 & ALLEX & 568.03 \\
\hline 58 & ED & 2282.52 & 1331 & BANTU & 1169.46 & $208 \mathrm{I}$ & LEXSM & 750.95 & 283 & LEMMATIZED & 568.03 \\
\hline 59 & $\mathrm{CF}$ & 2236.65 & $134 \mathrm{I}$ & DICTIONNAIRE & 1164.80 & $209 \mathrm{~F}$ & POS & 748.93 & 284 & BIBLIOGRAPHY & 565.35 \\
\hline 60 & ARTICLES & 2217.55 & 135 & OXFORD & 1120.67 & $210 \mathrm{~s}$ & STRUCTURE & 748.79 & 285 & THEORETICAL & 561.91 \\
\hline 61 & LINGUISTICS & 2198.63 & 136 & TLS & 1113.15 & $211 \mathrm{I}$ & DIFFERENT & 746.43 & 286 & FORM & 555.74 \\
\hline 62 & SPEAKERS & 2153.77 & 137 & GILLES & 1105.95 & 212 & CANADIAN & 743.56 & 287 & ORTHOGRAPHIC & 553.87 \\
\hline 63 & PRETORIA & 2145.64 & 138 & LE & 1096.98 & $213 \mathrm{~K}$ & KNOWLEDGE & 741.92 & 288 & METALANGUAGE & 551.73 \\
\hline 64 & TARP & 2134.20 & $139 \mathrm{I}$ & FUNCTIONS & 1090.11 & $214 \mathrm{~V}$ & WA & 741.80 & 289 & LEXICOGRAPHIE & 548.77 \\
\hline 65 & PRINSLOO & 2133.77 & $140 \mathrm{I}$ & LEXICOGRAPHICA & 1087.93 & $215 \mathrm{~F}$ & ETC & 734.21 & 290 & RAPONDA & 548.77 \\
\hline 66 & EXAMPLES & 2094.41 & 141 & COBUILD & 1083.54 & $216 \mathrm{I}$ & DESCRIPTION & 730.45 & 291 & MAURICE & 547.90 \\
\hline 67 & CORPORA & 2061.21 & 142 & MORPHOLOGICAL & 1072.77 & $217 \mathrm{~N}$ & MULTILINGUAL & 719.94 & 292 & HENNING & 545.84 \\
\hline 68 & UNIVERSITY & 2043.17 & $143 \mathrm{I}$ & DEM & 1068.77 & $218 \mathrm{~s}$ & SPEECH & 717.52 & 293 & JOFFE & 544.51 \\
\hline 69 & LEMMAS & 2010.79 & $144 \mathrm{I}$ & LEMMATA & 1059.53 & $219 \mathrm{~F}$ & PROVERBS & 715.76 & 294 & NEEDS & 539.75 \\
\hline 70 & DIALECTS & 1970.74 & 145 & COMPILED & 1057.86 & $220 \mathrm{l}$ & HADEBE & 711.44 & 295 & INTRALINGUAL & 539.15 \\
\hline 71 & AFRILEX & 1944.81 & 146 & WÖRTERBUCH & 1049.42 & $221 \mathrm{~A}$ & ADDENDUM & 711.21 & 296 & METALEXICOGRAPHY & 539.15 \\
\hline 72 & TERMS & 1884.03 & 1481 & HAUSMANN & 1047.65 & $222 \mathrm{~s}$ & SEARCH & 709.00 & 297 & MULTILEXICAL & 539.15 \\
\hline 73 & ZIMBABWE & 1841.84 & $147 \mathrm{l}$ & $\mathrm{KE}$ & 1029.89 & $223 \mathrm{~A}$ & ALSO & 708.81 & 298 & CATEGORIES & 535.78 \\
\hline 74 & ALRI & 1819.67 & $149 \mathrm{I}$ & EFL & 1011.61 & $224 \mathrm{I}$ & LABELS & 705.25 & 299 & JOURNAL & 532.78 \\
\hline 75 & VERB & 1791.75 & $150 \mathrm{C}$ & CHIMHUNDU & 991.65 & $225 \mathrm{~F}$ & FUNCTION & 700.96 & 300 & SUCH & 532.59 \\
\hline
\end{tabular}

